\title{
ANTIMICROBIAL EFFECTIVENESS OF ELECTRO-CHEMICALLY ACTIVATED WATER AS AN ENDODONTIC IRRIGATION SOLUTION
}

\author{
by \\ WAYNE PHILLIP WILLIAMS \\ BDS (Witwatersrand)
}

Supervisor: DR JT MARAIS

Submitted in partial fulfillment

of the requirements for the degree

MChD (Prosthodontics)

in the

FACULTY OF DENTISTRY

UNIVERSITY OF PRETORIA

PRETORIA

June 1999 


\section{DECLARATION}

I hereby declare that this dissertation, submitted by me in partial fulfillment of the requirements for the degree of $\mathrm{MChD}$ (Prosthodontics) at the University of Pretoria, has not previously been submitted for a degree at any other University
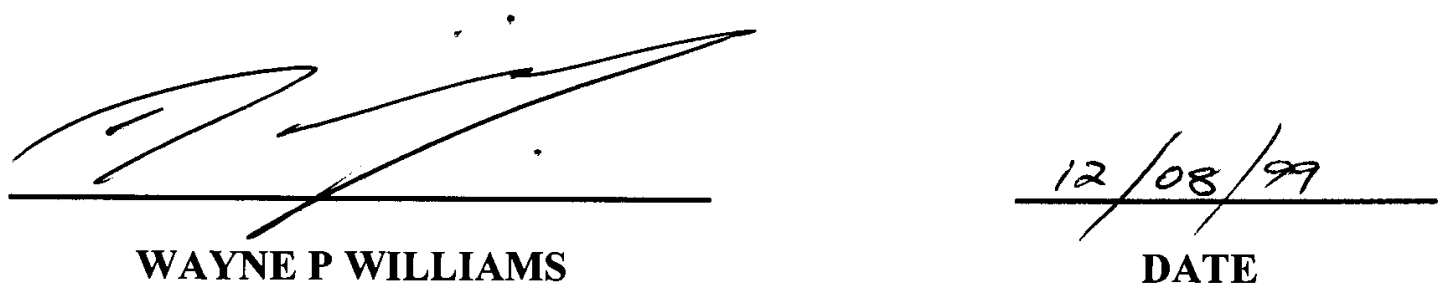
Declaration by Supervisor

As the supervisor of this dissertation submitted by Dr WP Williams entitled:

ANTIMICROBIAL EFFECTIVENESS OF ELECTROCHEMICALLY ACTIVATED WATER AS AN ENDODONTIC IRRIGATION SOLUTION

I approve the document for submission and further declare that an article for publication in the International Endodontic Journal has been prepared

This dissertation has not previously been submitted for any degree at any other university

This dissertation complies with all the rules as set out in the University of Pretoria yearbook (Reg G24(d); G24(e); G25; G32(e); G33; G37)

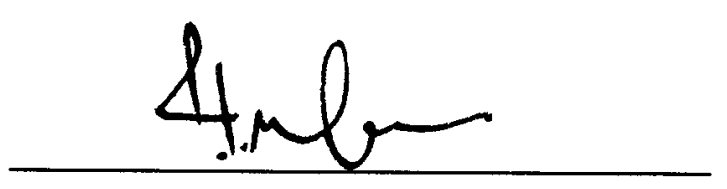

Dr JT Maris

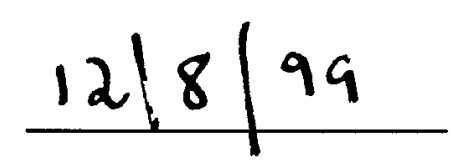

Date 


\section{ACKNOWLEDGEMENTS}

My sincere gratitude is expressed to Dr JT Marais for his continued enthusiasm, encouragement and intense devotion to the cause of this research. His integrity and irreproachable manner of conduct throughout this project has served as a fine example

I am indebted to the late Prof WJC Coetzee for his scientific accuracy and unselfish dedication to the correctness of this manuscript

I wish to thank the Centre for Stomatological Research - University of Pretoria, in particular, Dr Francien Botha for assistance with microbiological techniques as well as Ms I De Wet and Ms A Grobler for their unselfish devotion of time beyond their normal line of duty

Through his infinite sense of diplomacy and wisdom, Prof LH Becker remains a constant influence on my development as a young and inexperienced clinician and researcher in the field of prosthodontics. The belief and trust that he has placed in me, allowing me the freedom to experiment and experience all that has been in the past forty months, is certainly encouragement for any student from his mentor

Prof CH Driessen, an experienced and thorough researcher has been a constant source of positive criticism and encouragement. His assistance with SEM analysis is also appreciated

Prof PL Kemp, thank you for the way you have taught me to "think" about research and reporting on an international platform. "There are no answers, only interpretations"

Ms Laura Matzner did statistical revision. I am most grateful for her professional and prompt service

I will always be indebted to my family (Henriëtte, Warren and Rowan) for allowing me the time away from them to complete this work 


\section{SUMMARY}

The use of sodium hypochlorite $(\mathrm{NaOCl})$ as an endodontic irrigation solution is effective in eliminating microorganisms from the root canals of human teeth. The purpose of this in vitro study was to evaluate the antimicrobial effectiveness of electro-chemically activated water (ECA) as an endodontic irrigation solution. ECA is a solution comprising many different ions, molecules and radicals. Sixty caries-free, single root, adult, maxillary, anterior human teeth were used. The root canals were instrumented and irrigated with $\mathrm{NaOCl}$ in a similar method to that employed for in vivo root canal treatment. The external root surface of each tooth was sealed and the access cavity kept patent so that root canals could be inoculated with a suspension containing four bacteria ${ }^{1}$. The teeth were randomly divided into four groups $(n=15)$. Each group was irrigated ultrasonically, using solutions of distilled water (control), $\mathrm{NaOCl}(3.5 \%)$, and ECA, the latter at pH's 7.0 and 9.0 respectively. Antimicrobial effectiveness was established directly after irrigation and again seven days later, by counting colony forming units on blood agar plates and by spectrophotometric analysis. The surfaces of the root canals were visually examined by means of scanning electron microscopy. Large numbers of bacteria were present in the canals of teeth irrigated with distilled water. No bacteria were observed following irrigation with $\mathrm{NaOCl}$. Neither of the ECA solutions were found to be effective against all the bacteria. Although some reduction in the number of bacteria was evident in the ECA groups, this was not statistically significant $(p>0.05)$. Within the confines of this study ECA did not demonstrate antimicrobial effectiveness.

\footnotetext{
${ }^{1}$ Prevotella intermedia Porphyromonas gingivalis Enterococcus faecalis Actinobacillus actinomycetemcomitans
} 


\section{OPSOMMING}

Die gebruik van natriumhipochloriet $(\mathrm{NaOCl})$ as ' $\mathrm{n}$ endodontiese irrigeringsmiddel elimineer mikrorganismes in die wortelkanaalstelsel van menslike tande doeltreffend. Die doel van hierdie in vitro studie was om die antimikrobiale effektiwiteit van elektrochemies geaktiveerde water (ECA) as ' $n$ endodontiese irrigasie middel te evalueer. ECA is ' $n$ oplossing van verskeie ione, molekules en radikale. Sestig karies-vrye, enkelkanaal, volwasse, maksillêre, anterior menslike tande is gebruik in hierdie studie. Die wortelkanale is voorberei en geirrigeer met $\mathrm{NaOCl}$ volgens die metode wat gebruik word vir in vivo wortelkanaal behandeling. Die eksterne wortel oppervlak van elke tand is geseël en die toegangsopening oopgehou sodat die wortelkanale geinokuleer kon word met ' $n$ suspensie van vier bakterië'. Die tande is lukraak in vier groepe $(n=15)$ verdeel. Die vier groepe is elk ultrasonies geirrigeer - die eerste groep met gedistilleerde water (kontrole); die tweede met $\mathrm{NaOCl}$ (3.5\%) en die derde en vierde met ECA van pH 7.0 en 9.0 onderskeidelik. Antimikrobiale effektiwiteit is vasgestel direk na irrigasie en weer na sewe dae, deur tellings van kolonievormende eenhede op bloed agar plate en deur spektrofotometriese analise. Die dentinale oppervlaktes van die wortelkanaal is ondersoek met die gebruik van skandeer elektron mikroskopie. Groot getalle bakterië was teenwoordig in die kanale van die tande wat met gedistilleerde water geïrrigeer is. Geen bakterië kon waargeneem word na irrigasie met $\mathrm{NaOCl}$ nie. Nie een van die ECA oplossings was effektief teen al die bakterië nie. Alhoewel ' $n$ vermindering in die getal bakterië in die ECA groepe gevind is, was dit nie statisties betekenisvol nie $(p>0.05)$. Binne die beperkinge van hierdie studie was daar geen duidelike bewys van die antimikrobiale effektiwiteit van ECA nie.

\footnotetext{
${ }^{2}$ Prevotella intermedia Porphyromonas gingivalis Enterococcus faecalis Actinobacillus actinomycetemcomitans
} 


\section{LIST OF CONTENTS}

\section{CHAPTER 1}

Introduction

\section{CHAPTER 2}

Literature Review

2.1 Technical and biological problems with the use of sodium hypochlorite

2.2 Alternatives for sodium hypochlorite

\section{CHAPTER 3}

Purpose

\section{CHAPTER 4}

Materials and Methods

4.1 Preparation of teeth 9

$\begin{array}{lll}4.2 & \text { Preparation for first microbiological analysis } & 10\end{array}$

$\begin{array}{lll}4.3 & \text { Irrigation of teeth } & 14\end{array}$

$\begin{array}{lll}4.4 & \text { Second microbiological analysis } & 14\end{array}$

$\begin{array}{lll}4.5 & \text { Statistical analysis } & 15\end{array}$

$\begin{array}{ll}\text { 4.6 Scanning electron microscopy } & 15\end{array}$

\section{CHAPTER 5}

Results 
CHAPTER 6

Discussion

\section{CHAPTER 7}

Conclusion

REFERENCES

ADDENDA 


\section{LIST OF FIGURES}

Figure

1 SEM - Irrigation with $\mathrm{NaOCl}(\mathbf{x 5 0 0})$

2 SEM - Irrigation with ECA (x500)

3 SEM - Irrigation with $\mathrm{NaOCl}(\mathbf{x 2 5 0 0})$

4 SEM - Irrigation with ECA (x2500)

5 STEDS unit for the production of ECA

6 Blood agar plate from pilot study to demonstrate antimicrobial properties of ECA

7 Higher magnification of blood agar plate seen in Fig.6 7

8 Teeth used for this study

9 Spiral filler introduction of calcium hydroxide $\left(\mathrm{Ca}(\mathrm{OH})_{2}\right)$

(note the sealed external root surface)

10 Sterile pipette for obtaining samples from root canal

11 Placing sampled solution onto the blood agar plate

12 Standardized suspensions of bacteria (Mac Farland-1)

13 Anaerobic bacteria imported from ATCC (USA)

14 Tooth removed from BHI broth and held upright (note BHI broth in beaker)

15 SEM -no irrigation (x6000)

16 SEM - distilled water (x6000)

17 SEM - NaOCI (x1500)

18 SEM - NaOCl (x6000)

19 SEM - ECA pH 7.0 (x1500)

20 SEM - ECA pH 7.0 (x6000)

21 SEM - ECA pH 9.0 (x1500)

22 SEM - ECA pH 9.0 (x6000) 


\section{LIST OF TABLES}

Table

1 Irrigation solutions and Groups

2 Stages at which teeth were removed from the study for

SEM examination

3 Colony forming units and spectrophotometric values measured immediately after irrigation of root canals with four different solutions

4 Colony forming units and spectrophotometric values measured seven days after irrigation of root canals with four different solutions

5 Increase in colony forming units and spectrophotometric values for the period directly following irrigation to the seventh day post-irrigation (Table 4 minus Table 3)

6 Dunnett's test results on spectrophotometric values, comparing each of Groups B, C and D to Group A (control)

7 Results of paired t-test on spectrophotometric values for bacterial growth over the seven day period after irrigation with four different solutions 


\section{LIST OF ADDENDA}

Appendix A Colony forming units and spectrophotometric analysis measured directly after irrigation

Appendix B

Colony forming units and spectrophotometric analysis

measured seven days after irrigation

Appendix C

Molecules and ions contained in ECA 


\section{CHAPTER 1}

\section{Introduction}

The treatment of choice for periapical disease is elimination of microorganisms and their products from the root canal system by means of a root canal treatment. The ADA (American Dental Association) estimates that by the year 2000, thirty million root canals will be treated annually in the USA alone (American Association of Endodontics recertification document, (1989)).

The procedure of root canal treatment in human teeth is often described by the following three terms: Cleaning, Shaping, Filling. The "cleaning" phase consists essentially of the irrigation of the canal with a liquid agent (irrigation solution). The objectives of this phase are destruction of microorganisms; dissolution of vital and necrotic tissue; flushing away of organic debris and bacterial remnants; lubrication of endodontic instruments; prevention of blockage of canals by the by-products of the "shaping" phase, and removal of the smear layer. The focus of this study is on the destruction of microorganisms within the root canal system.

$\mathrm{NaOCl}$ at a concentration of between 2.5 and $5.25 \%$ is universally accepted as the irrigant of choice for root canal therapy (Cheung and Stock, 1993; Gulabivala and Stock, 1995; Walton and Rivera, 1996).

$\mathrm{NaOCl}$ is delivered into the root canal by means of a syringe and needle or an ultrasonic unit. The use of an ultrasonic unit as an irrigation instrument is considered to be superior to the conventional syringe and needle (Cheung and Stock, 1993; Cameron, 1995).

$\mathrm{NaOCl}$ achieves the above objectives of the "cleaning" phase with remarkable efficiency, but is also associated with and may cause many complications and problems, some of which may even be life threatening (Jeansonne and White, 1994). 


\section{CHAPTER 2}

\section{Literature Review}

\subsection{Technical and biological problems with the use of sodium hypochlorite}

$\mathrm{NaOCl}$ is extremely toxic to living tissue. Extrusion of $\mathrm{NaOCl}$ through the apices of teeth causes severe pain, swelling and necrosis (Brown et al., 1995). Accidental extrusion of $\mathrm{NaOCl}$ into the maxillary sinus may cause serious complications and even death (Cymbler and Ardakani, 1994). The use of local anaesthetic cartridges filled with $\mathrm{NaOCl}$ can also cause severe complications if inadvertently injected into a patient's soft tissue (Caliskan, Turkun and Alper, 1994). Not only is the use of such a cartridge system dangerous, but is also more time consuming as each cartridge must be sterilized and filled.

Because of the corrosive nature of $\mathrm{NaOCl}$, ultrasonic units used for canal irrigation are prone to mechanical blockage and breakdown. Maintenance of such systems is time consuming and expensive. Due to the vile taste and odor of $\mathrm{NaOCl}$, accidental spillage into the mouth during root canal treatment results in severe discomfort for the patient. This invariably requires the patient to rinse the mouth, an action that defeats the object of "cleaning" the root canal, because saliva containing great numbers of bacteria may enter the tooth and root canal during the rinsing process (Yesilsoy et al., 1995).

Because of the above-mentioned problems, dentists often neglect the "cleaning" phase of root canal treatment. This may result in failure of the root canal treatment and a host of other complications such as dental abscesses, root end surgical operations, general anesthesia, hospitalization, further endodontic failures and loss of teeth that had previously been treated.

Substrate adherence capacity of inflammatory macrophages has been shown to decrease significantly with the use of $\mathrm{NaOCl}$ (Jimenez-Rubio, et al, 1997). Given that adhesion is the first step in the phagocytic process of macrophages and in antigen presentation, $\mathrm{NaOCl}$ could inhibit macrophage function and reduce inflammatory reactions in periapical tissues when used in root canal therapy. 


\subsection{Alternatives for sodium hypochlorite}

Water, disinfectants and various detergents have been evaluated for possible use as root canal irrigants. Antimicrobial properties of calcium hydroxide $\left(\mathrm{Ca}(\mathrm{OH})_{2}\right)$, chlorhexidine and camphorated paramonochlorophenol were examined by Barbosa et al., (1997). Nd-YAG laser irradiation (Fegan and Steiman, 1995), citric acid (Georgopoulou et al., 1994), oxidative potential water (Hata et al., 1996), chlorhexidine gluconate (Jeansonne and White, 1994) and gluteraldehyde (JimenezRubio et al., 1997) have also been reported on as possible intracanal agents. None of these have been accepted as a replacement for $\mathrm{NaOCl}$ for root canal irrigation.

Electro-chemically Activated Water: Russian scientists developed a process whereby they could produce ECA. To date, only one reference to this solution is to be found in western scientific literature (Marais, 1998). Marais irrigated one group of root canals with ECA (catholyte) and another with $\mathrm{NaOCl}(3.5 \%)$, with solutions being delivered from an ultrasonic unit. Root canal surfaces were examined using a scanning electron microscope (Fig 1, 2, $3 \& 4$ ). ECA produced surfaces that appeared as clean as those for the $\mathrm{NaOCl}$ group. Marais also showed that ECA removed the smear layer, from many surfaces of the canal.

\section{Fig 1: Irrigation with $\mathrm{NaOCl}(\mathbf{x 5 0 0})$}

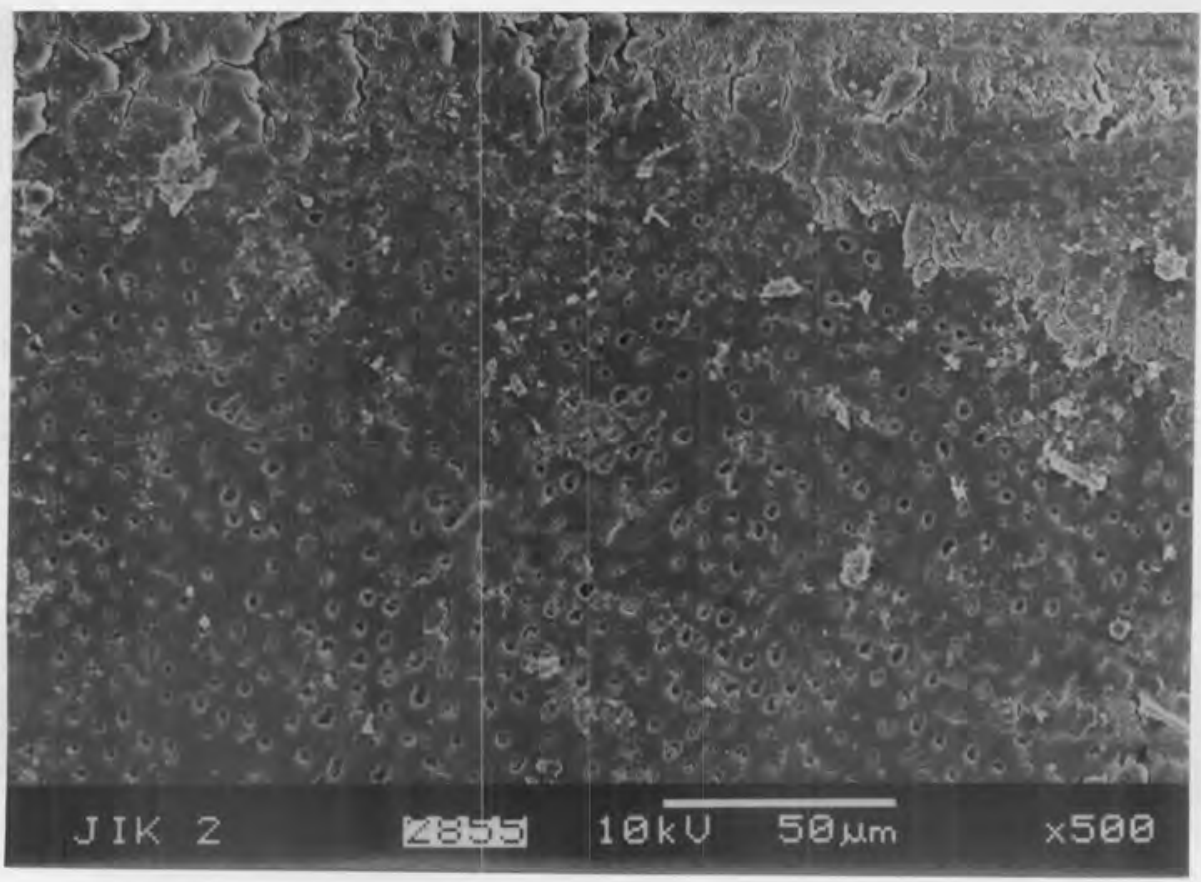


Fig 2: Irrigation with ECA (x500)

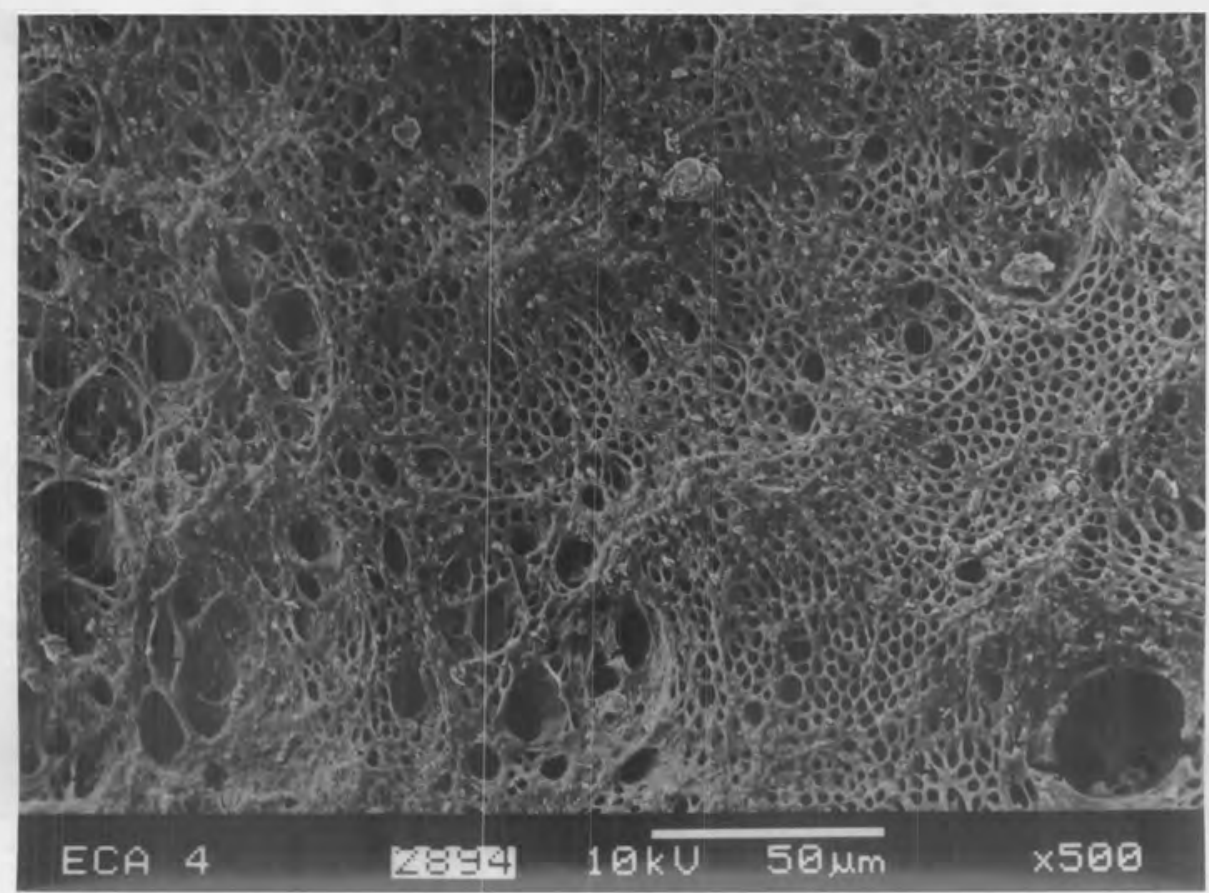

Fig 3: Irrigation with $\mathrm{NaOCl}(\mathrm{x} 2500)$

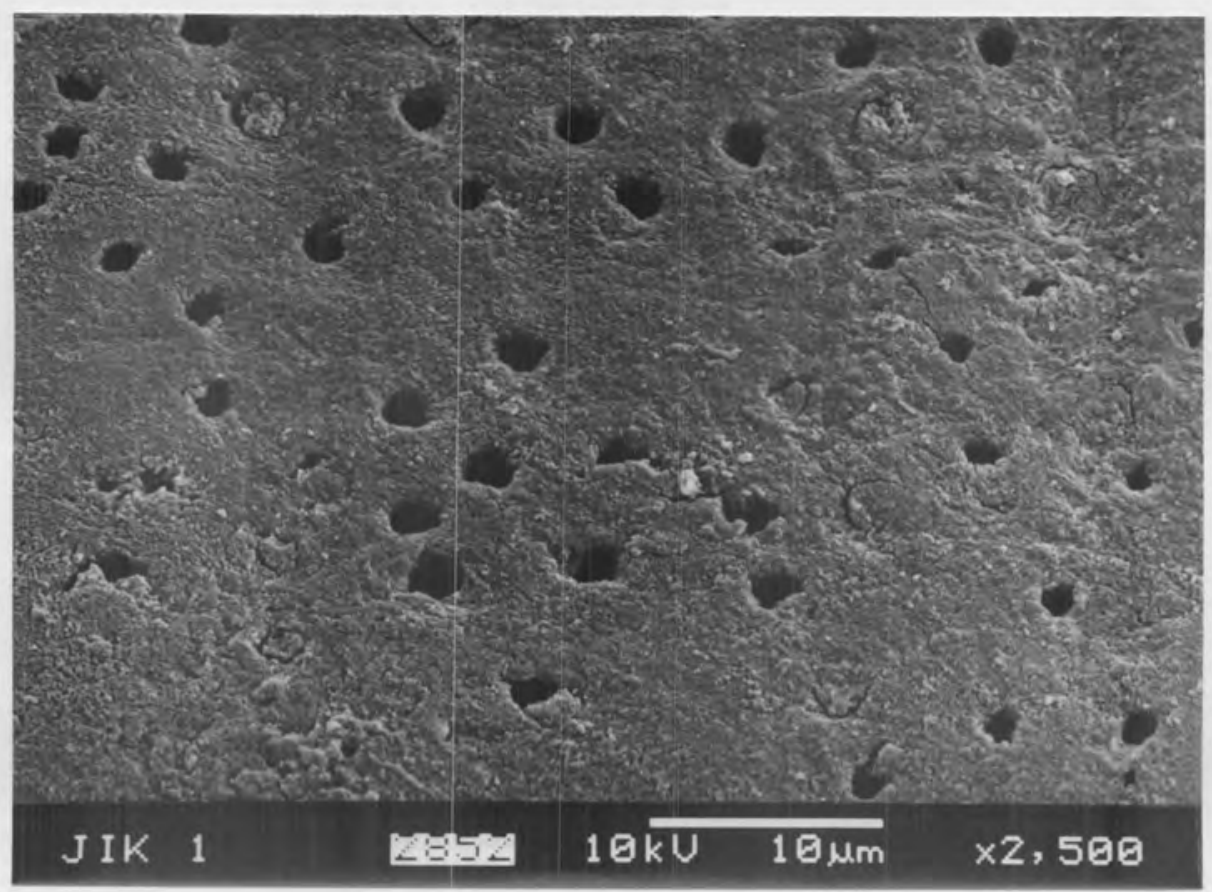


Fig 4: Irrigation with $\operatorname{ECA}(\mathbf{x 2 5 0 0 )}$

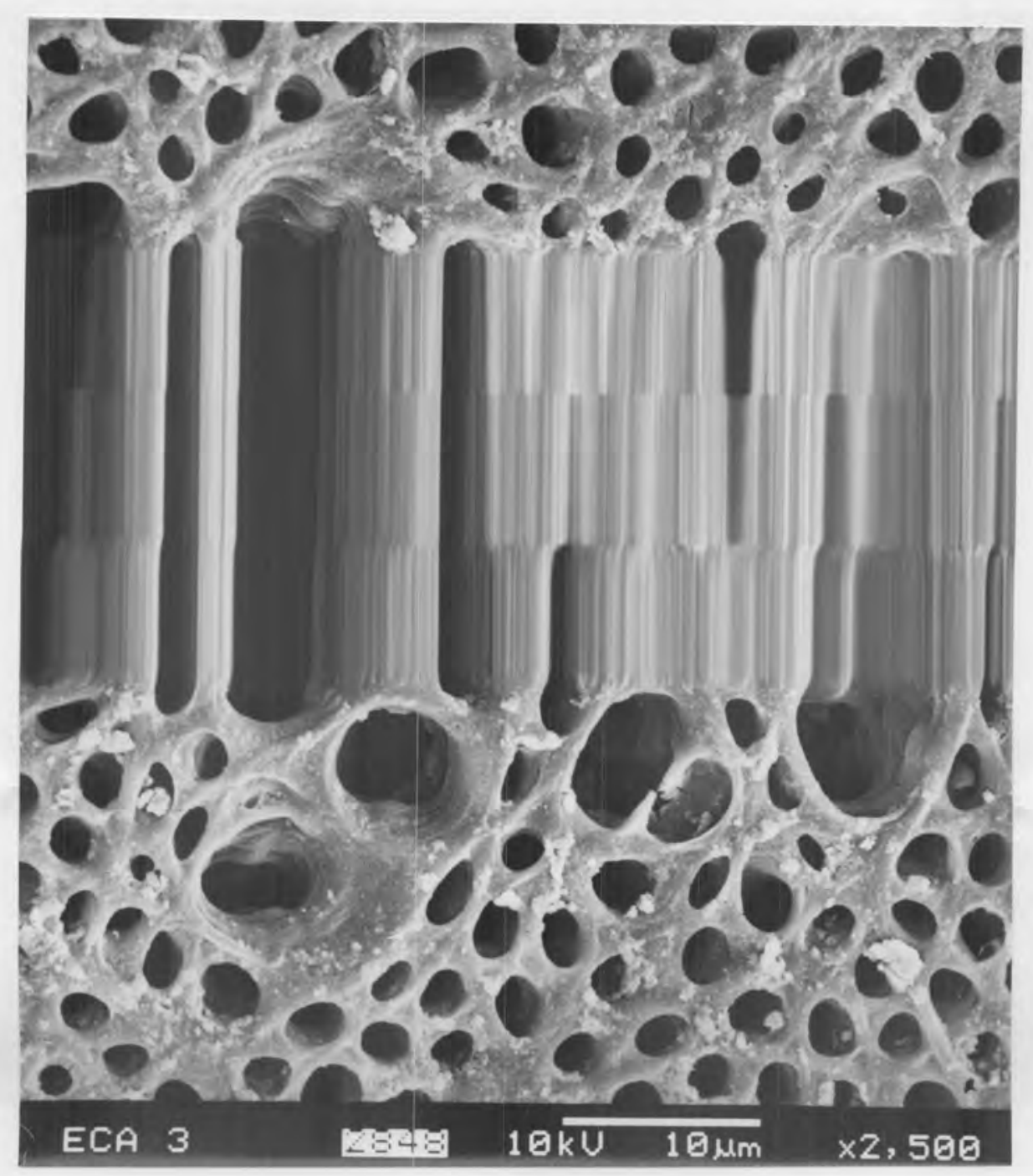

ECA is the subject of more than 300 Russian patents. More than 20000 units producing ECA are in operation in Russian hospitals today. The physical and chemical nature of ECA is not yet fully understood. The solution supposedly exists in a metastable or disequilibrious state after production and contains many free radicals and a variety of molecules and ions (see Appendix III, pg. 30). In the metastable state the solution has a very high oxidation-reduction potential. Two types of ECA solution are produced:

- Anolyte, with a high oxidation potential (plus 400 to plus 1200 millivolts). It is possible to produce acidic, neutral or alkaline anolyte $(\mathrm{pH} 2-9)$. Anolyte is claimed to be antimicrobial (according to the manufacturers) ${ }^{1}$.

- Catholyte, an alkaline solution ( $\mathrm{pH} 7-12)$ with a high reduction potential (minus 80 to minus 900 millivolts, measuring current in opposite direction). Catholyte is reputed to have a strong cleaning or detergent effect.

\footnotetext{
${ }^{1}$ STEDS, Radical Waters (Pty)Ltd., P.O Box 10844 Vorna Valley, 1686, South Africa
} 
Both these solutions remain in the metastable state for approximately 48 hours before the solution returns to the stable state, becoming inactive once more.

ECA is produced from tap water with the addition of saline solution in a special unit (Fig 5) that houses a unique flow-through electrolytic module (FEM).

Fig 5: STEDS unit for the production of ECA

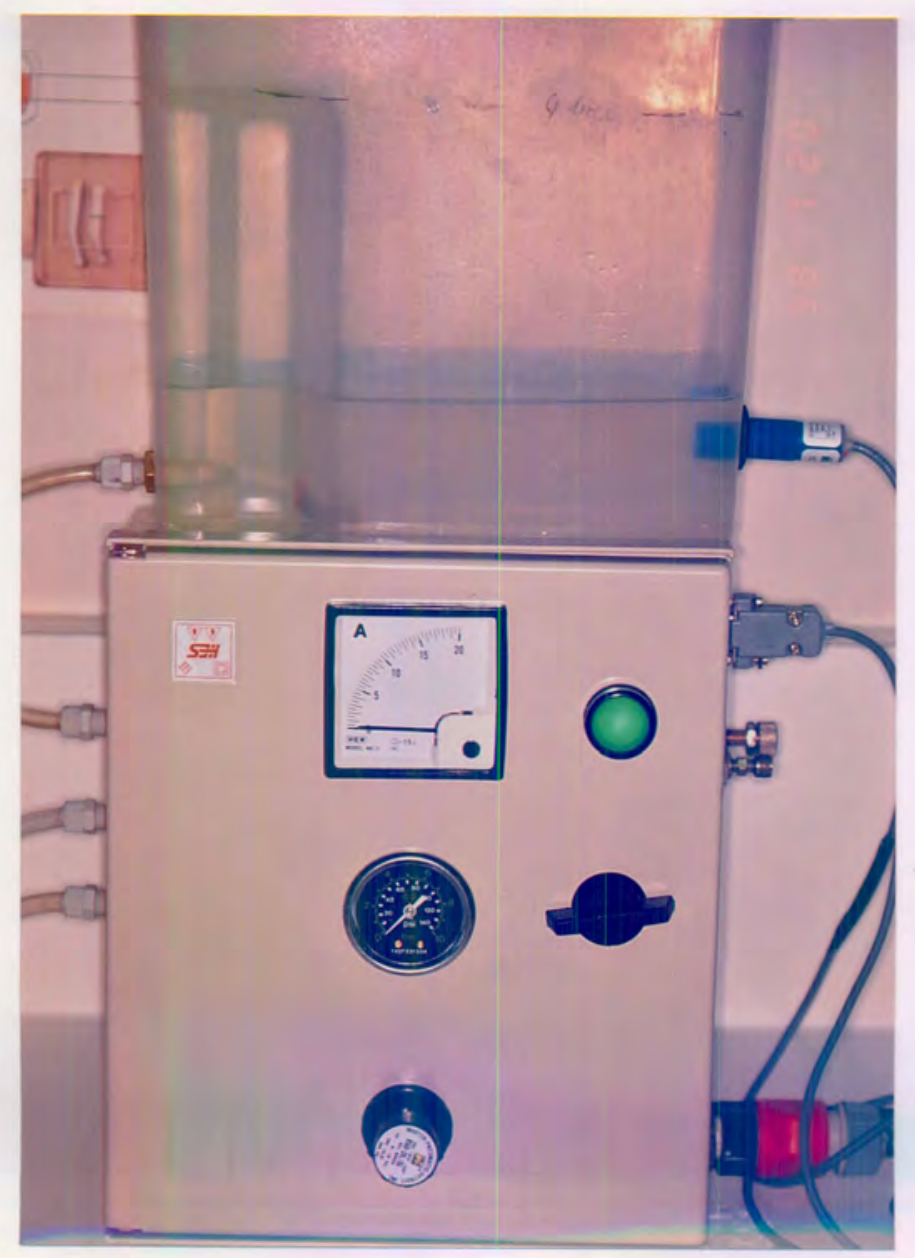

The FEM contains the anode, made from titanium and coated with ruthenium -oxide, iridium and platinum, and the cathode, made from titanium coated with pyro-carbon and glass-carbon. A diaphragm consisting of ultra-filtration, electro-catalytic ceramics on a bed of zirconium, yttrium, aluminium and niobium-oxides, separates the anode and cathode. 
A pilot study was conducted in which the same anaerobic bacteria used in this study were streaked out onto blood agar plates. ECA solutions with different $\mathrm{pH}$ values absorbed into blotting paper were placed onto the agar plates and incubated anaerobically at $37^{\circ} \mathrm{C}$ for 7 days. In a similar manner to antibiotic-sensitivity testing, successful inhibition of growth of all four bacteria for some distance around the ECA

solutions was demonstrated (Fig $6 \& 7$ - Prevotella intermedia).

Fig 6: Pilot study to demonstrate antiMicrobial properties of ECA

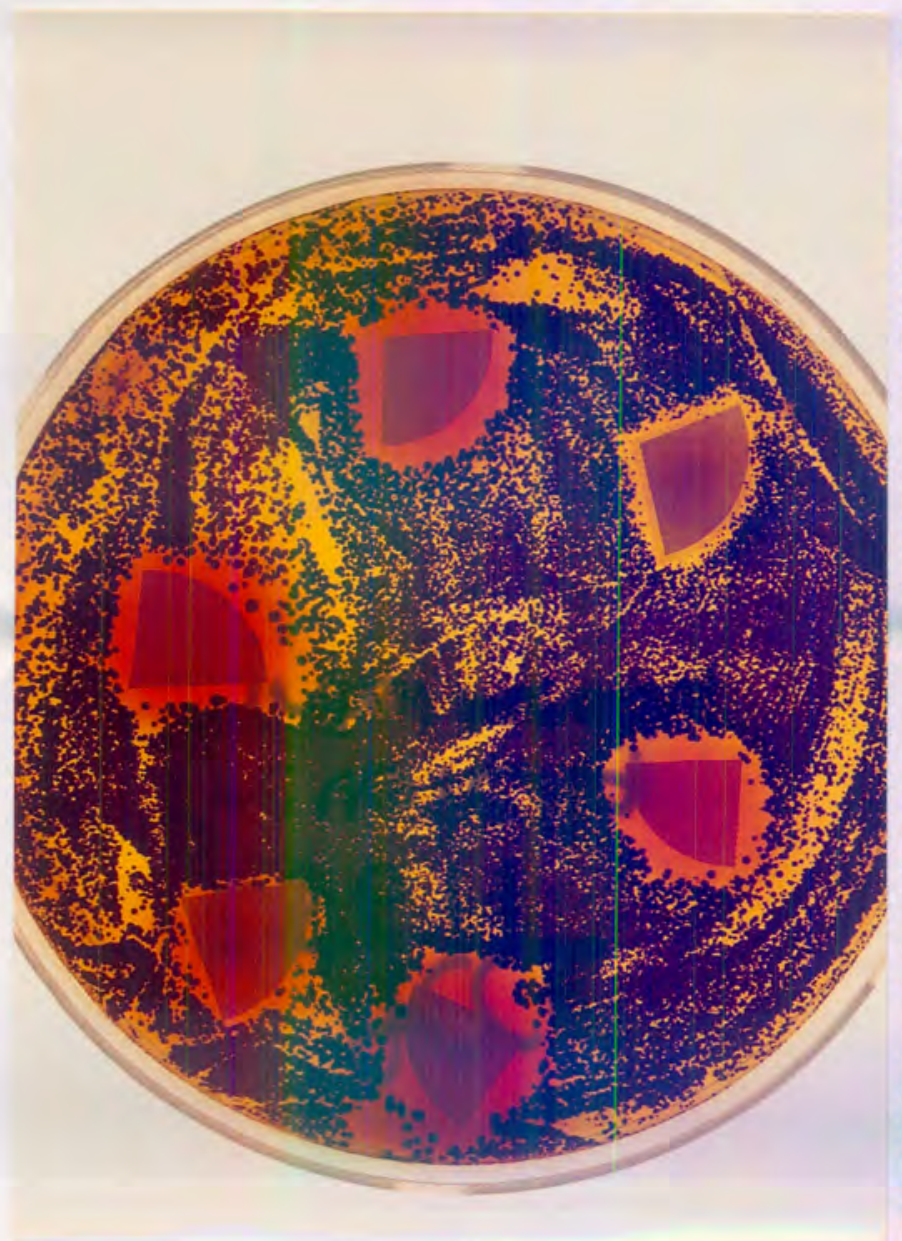

Fig 7: Higher magnification of blood agar plate seen in Fig 6

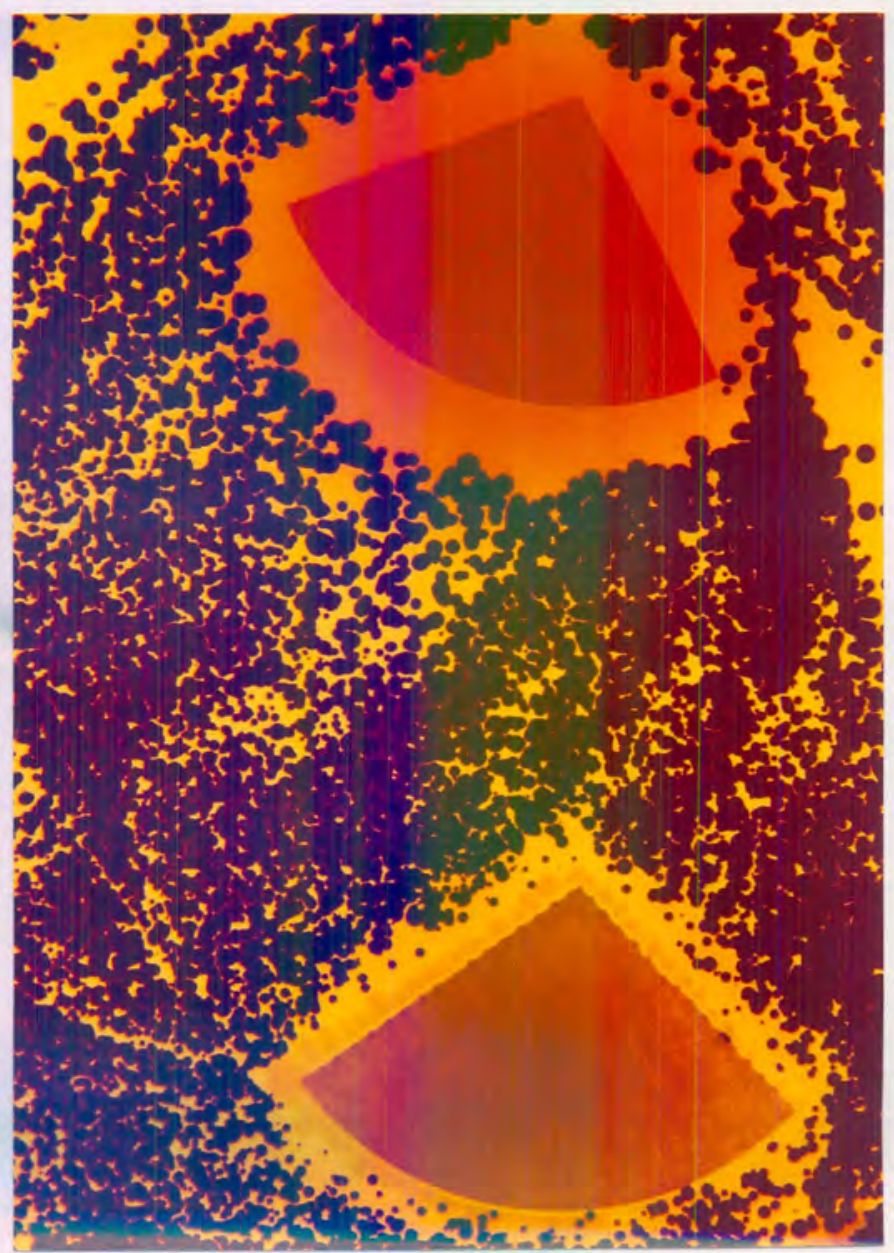

The research of Hata et al., 1996, reported on the effectiveness of so-called oxidative potential water (OPW) as a root canal irrigant. The authors, from Osaka Dental University, Japan, reported favorably on the cleaning ability of OPW to clean debris from canal walls. It is not exactly clear what OPW is, but there is subjective reason to believe that it may be similar to ECA and being produced by similar technology ${ }^{2}$.

\footnotetext{
${ }^{2}$ Super Mini-Water, Janix Inc., Atsugi, Japan
} 


\section{CHAPTER 3}

\section{Purpose}

The purpose of this in vitro study was to evaluate the antimicrobial effectiveness of ECA on a selected group of anaerobic bacteria in root canals of extracted human teeth.

\section{CHAPTER 4}

\section{Materials and Methods}

Sixty caries-free, single rooted, adult, maxillary, anterior human teeth were used for the study (Fig 8).

Fig 8: Teeth used for this study

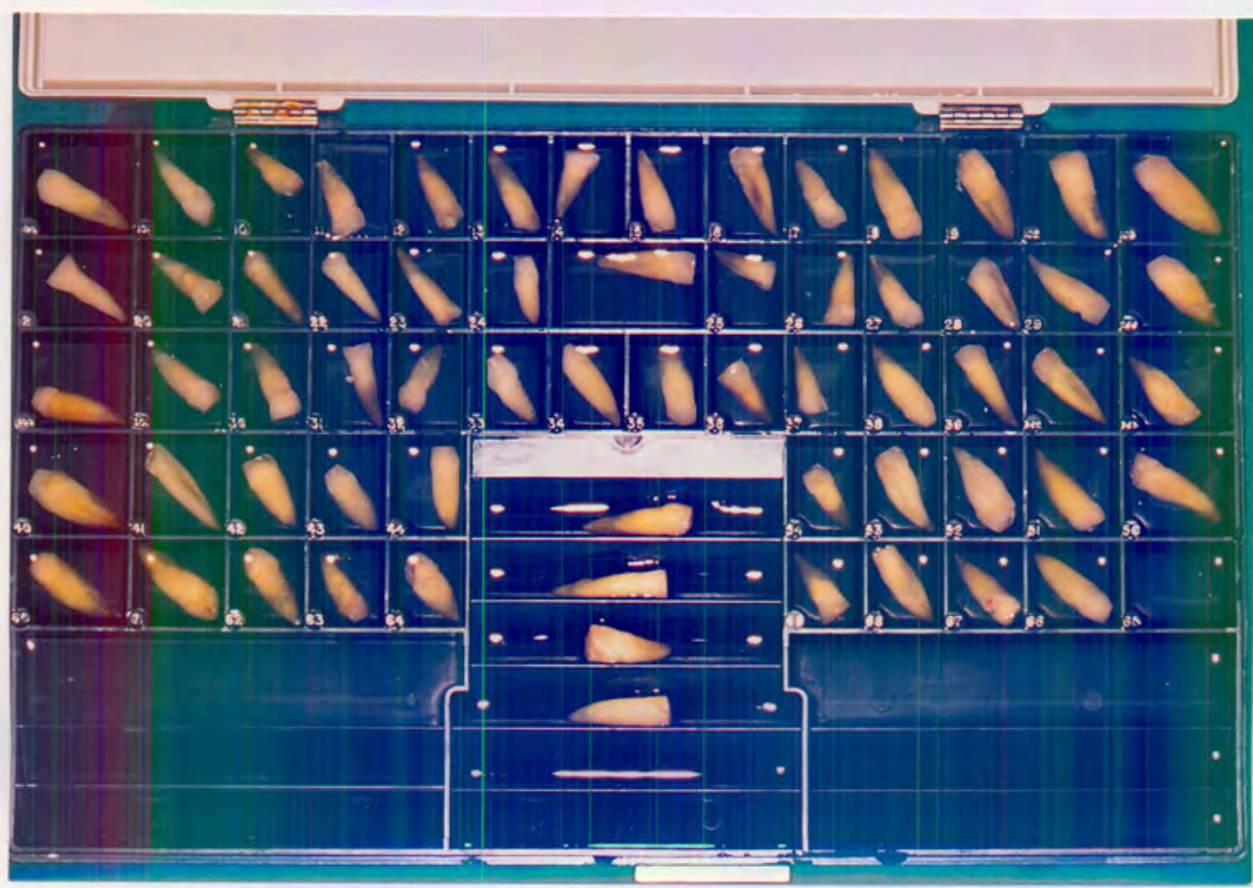

Teeth were collected from the extraction clinic of the University of Pretoria and rinsed under cold running tap water and stored in distilled water at $4^{\circ} \mathrm{C}$ for 1 week.

Radiographs were taken of each tooth to identify and eliminate teeth with aberrant canal forms, caries, internal or external resorption, calcifications, multiple canals, or any other condition, which may influence the experimental procedure. 


\subsection{Preparation of teeth}

Conventional access cavities were prepared using diamond burs in a turbine driven handpiece and long shank round burs in an air-motor driven handpiece. Canals were explored using number $08 \mathrm{X}^{\mathrm{X}}$ files $^{3}$, confirming apical patency and establishing working length visually, for each individual tooth. The working length of each tooth was noted at the time of preparation. The coronal two thirds of the canal was prepared using a nickel-titanium instrument in a rotary handpiece ${ }^{4}$.

After each size file, and intermittently during the preparation procedure, canals were irrigated with a $3.5 \%$ solution of $\mathrm{NaOCl}^{5}$, delivered from an ultrasonic unit ${ }^{6}$.

The apical third of each canal was prepared to a minimum ISO size 30 , using a series of hand-files. Once again, after each size file, the canals were thoroughly irrigated as described above. Following apical preparation, the canals were smoothly tapered using a step-back procedure with X-files and rotary nickel titanium files, again with copious irrigation $(\mathrm{NaOCl})$.

The apices of the teeth were sealed with a resin modified glass-ionomer cement ${ }^{7}$. The remaining root surface was coated with a double layer of nail varnish, to isolate the internal root canal environment (Behrend, Cutler and Gutmann, 1996). Each canal was finally flushed with $\mathrm{NaOCl}$, dried with a paper point and filled with calcium hydroxide $^{8}\left(\mathrm{Ca}(\mathrm{OH})_{2}\right)$ powder (Turkun and Cengiz, 1997), mixed with sterile water to a creamy mixture and introduced into the canal with a spiral filler (Fig 9)

\footnotetext{
${ }^{3}$ Hyflex X-File, Hygenic Corporation, Akron, Ohio, USA

${ }^{4}$ ProFile Series 29, Maillefer, Ballaigues, Switzerland

5 Jik, Reckitt Colman, Elandsfontein, South Africa

${ }^{6}$ Piesoelectric, Siemens, Germany

${ }^{7}$ Advance, Caulk/Dentsply, Milford, USA

${ }^{8}$ Calcium hydroxide, Merck, D-6100, Darmstadt, Germany
} 
Fig 9: Spiral filler introduction of $\mathrm{Ca}(\mathrm{OH})_{2}$ (note the sealed external root surface)

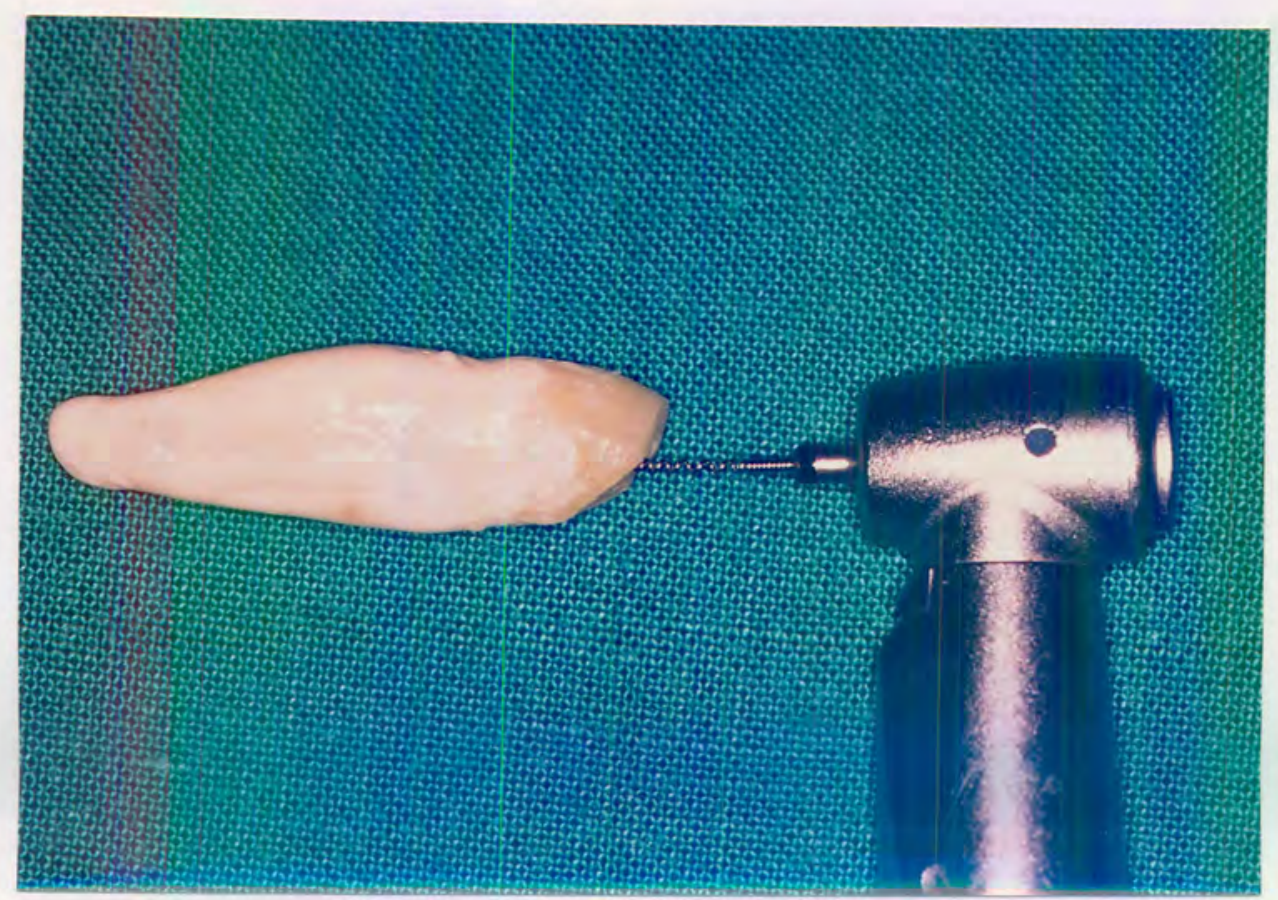

A cotton wool pellet was placed into the pulp chamber and the access cavity sealed with a zinc oxide eugenol material ${ }^{9}$. After a 7-day storage period in de-ionized water $\left(37^{\circ} \mathrm{C}\right)$, access to the canals was once more established by removing the zinc oxide eugenol material and cotton wool pellets.

The aim of the preparation, irrigation, filling $\left(\mathrm{Ca}(\mathrm{OH})_{2}\right)$ and storage procedure was to produce tapered, sterile root canals. Sterility was maintained for the duration of the experiment, by working in a laminar flow cabinet in a positive sterile airflow laboratory, and using sterilized instrumentation, gloves and masks.

\subsection{Preparation for first microbiological analysis}

The teeth were placed in sterile Ringer's solution $\left(22^{\circ} \mathrm{C}\right)$ for five 24-hour cycles, Ringer's solution being replaced with a fresh solution after each cycle. This was done to remove $\mathrm{NaOCl}$ and $\mathrm{Ca}(\mathrm{OH})_{2}$ from the canals and dentinal tubules.

25 microlitre $(\mu \mathrm{l})$ sterile Ringer's solution was injected, using a sterile pipette, into each canal and aspirated (Fegan and Steiman, 1995)(Fig 10).

\footnotetext{
${ }^{9}$ IRM, Caulk/Dentsply, Milford, USA
} 
This procedure was repeated three times, serving as a rinsing procedure. The aspirated Ringer's solution was placed onto a blood agar plate (Fig 11) and spread,

using a sterile glass rod (Harrigan and McCance, 1970).

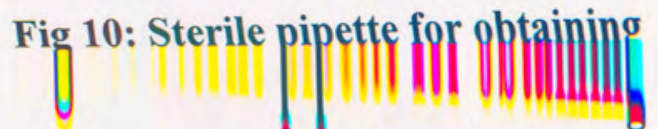

samples from root canal

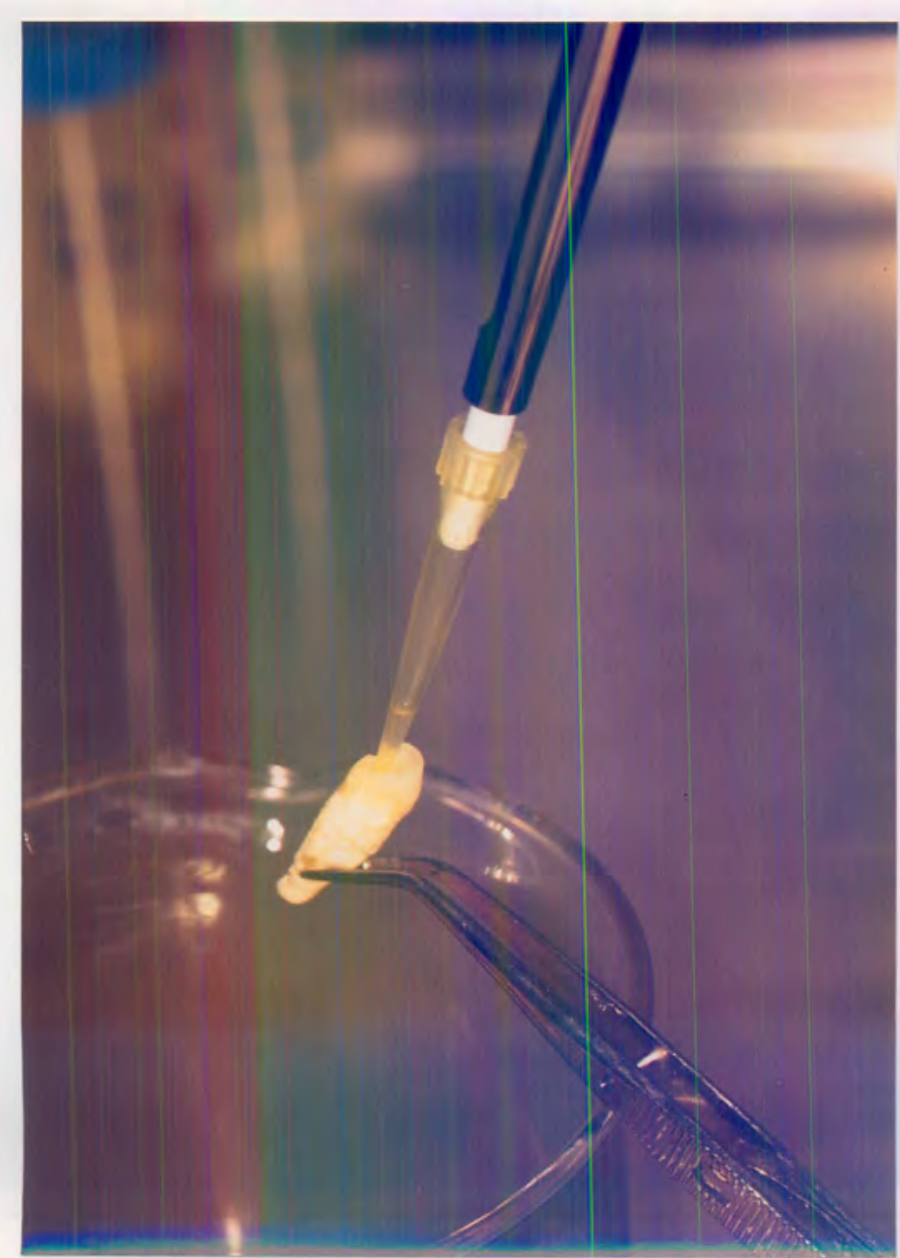

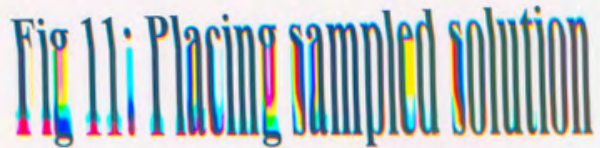

onto blood agar plate

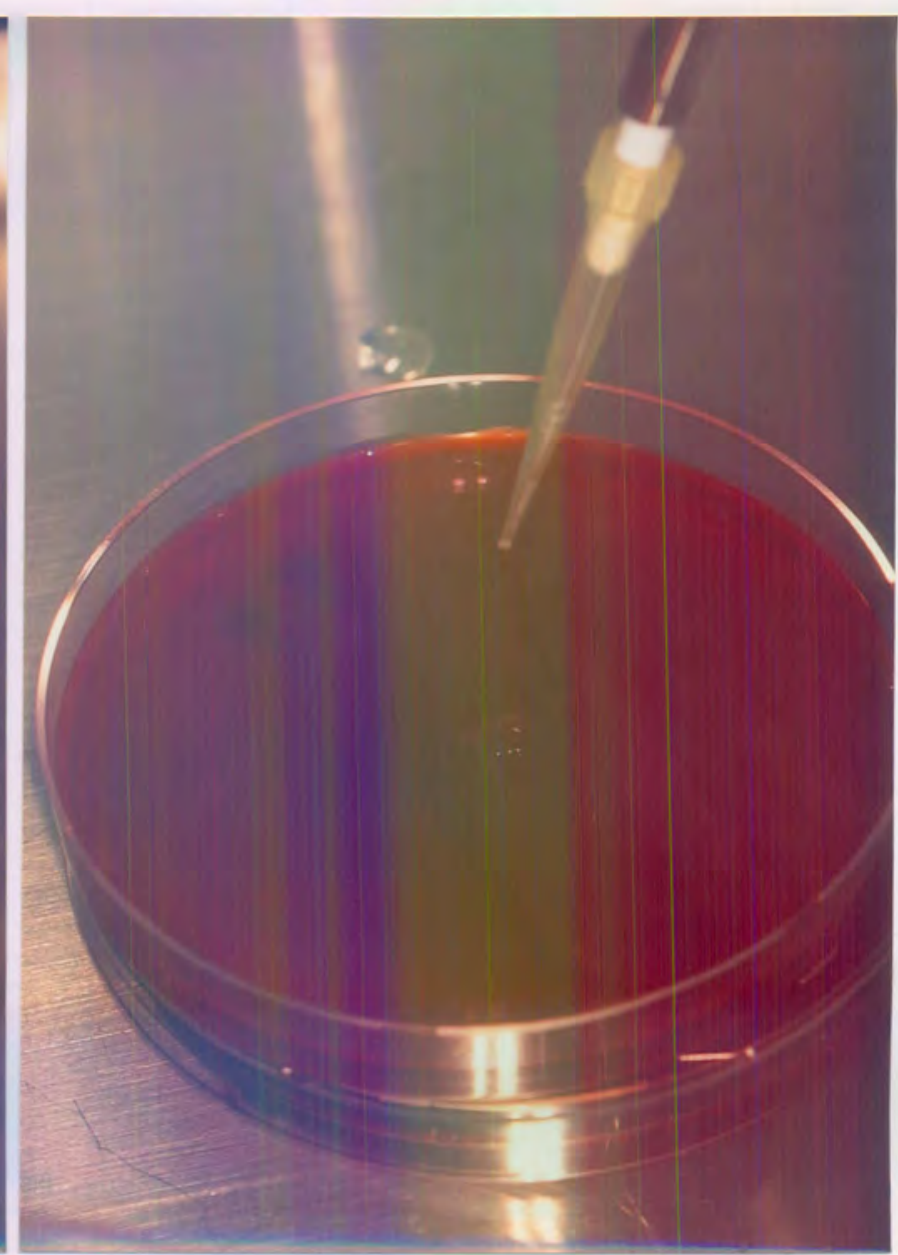

The plates were incubated anaerobically $\left(\right.$ Anerocult ${ }^{10}$ ) at $37^{\circ} \mathrm{C}$ for seven days. All cultures were negative at seven days, confirming absence of anaerobic bacteria within the root canals. Bacterial standardization (Fig 12) was done by using a MacFarland Standard-1 suspension and spectrophotometry ${ }^{11}$ at $540 \mathrm{~nm}$.

\footnotetext{
${ }^{10}$ Anerocult $A \circledR$, Merck GaA, 64271 Darmstadt, Germany

${ }^{11}$ GBC -uv/vis 916. Spectrophotometer (Wirsam), GBC Scientific Equipment, Melbourne, Australia
} 
Calibrated suspensions of 2 obligate ${ }^{12,13}$ and 2 facultative ${ }^{14,15}$ anaerobic bacteria (Fig 13), were prepared and inoculated into $500 \mathrm{ml}$ brain-heart-infusion (BHI) to form a broth (Kwang-ShikBae et al., 1997; Siqueira et al., 1997; Siqueira and de Uzeda, 1996).

\section{Fig 12i Standardized suspensions of bacteria (Mac Farland-1)}

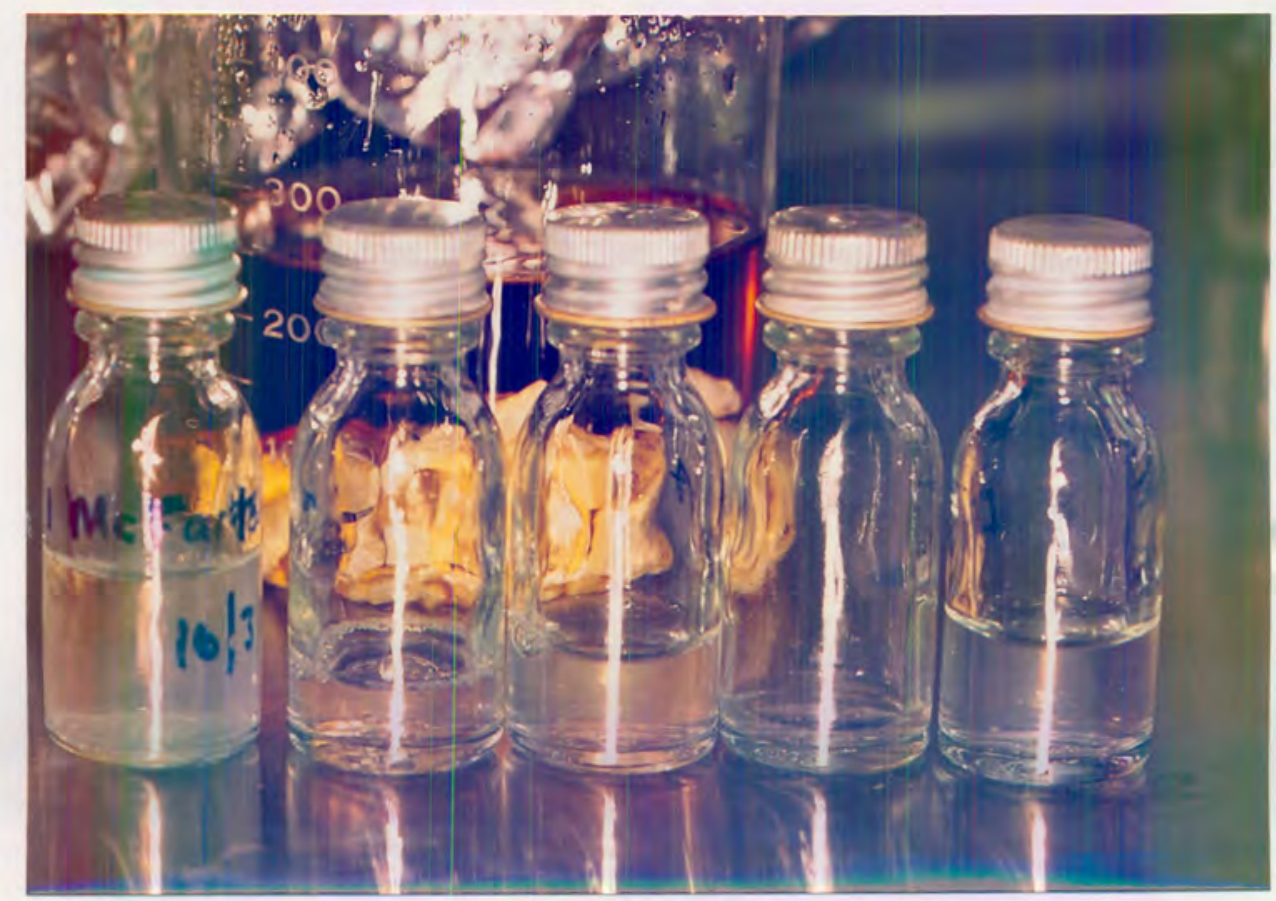

Fig 13: Anaerobic bacteria imported from - ATCC(USA)

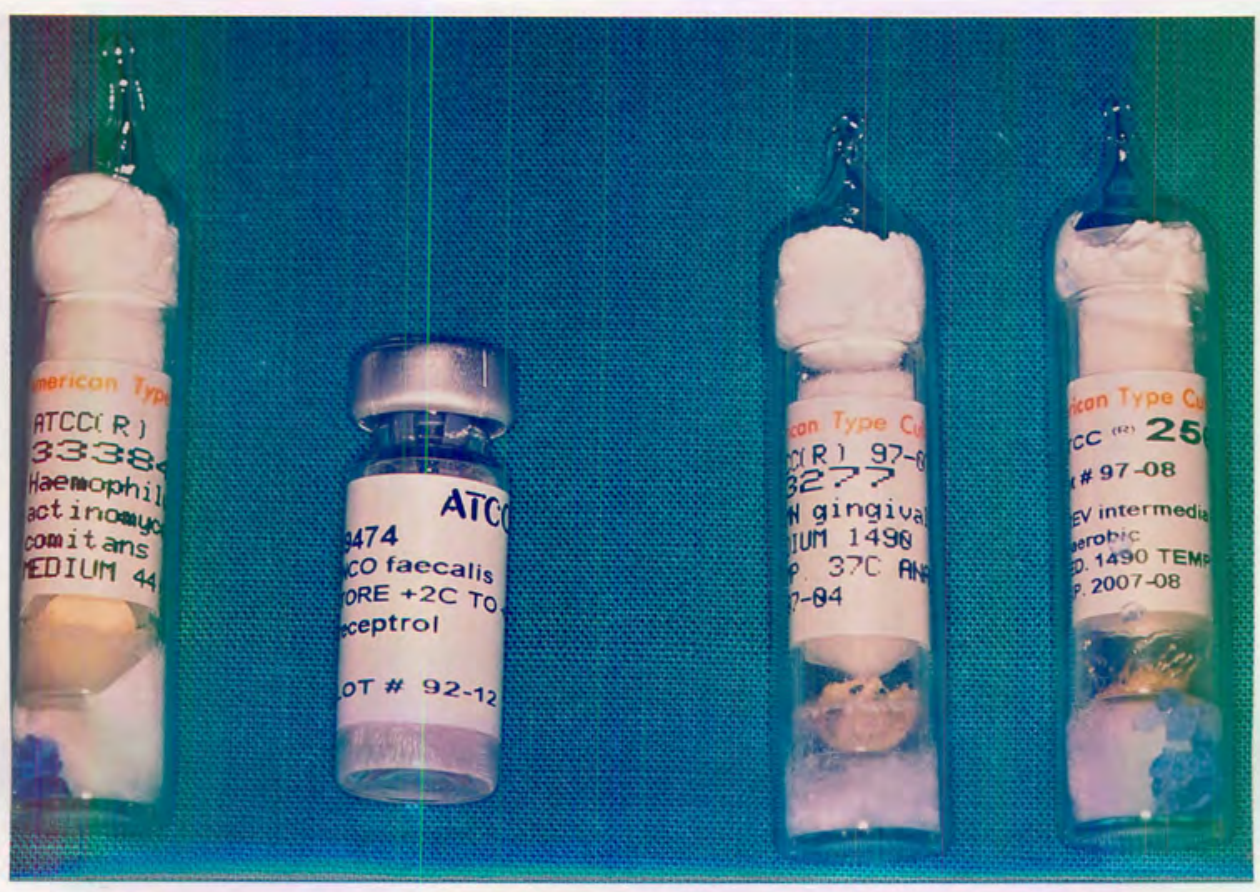
${ }^{12}$ Prevotella intermedia
ATCC No.25611
${ }^{13}$ Porphyromonas gingivalis
ATCC No. 33277
${ }_{15}^{14}$ Enterococcus faecalis
ATCC No.49474
${ }^{15}$ Actinobacillus actinomycetemcomitans
ATCC No. 33384 
Dilution of bacteria (for calibration) was as follows:
$P$ gingivalis
$=133 \times 10^{3} \quad P$ intermedia
$=5 \times 10^{3}$
E faecalis
$=420 \times 10^{3}$ A actinomycetemcomitans $=2 \times 10^{3}$

The morphological appearance of the individual organism and the principles of opacity and absorbency related to spectrophotometry, determine that a smaller bacteria will be inoculated in higher numbers to achieve the same spectrophotometric reading, as for a larger microorganism.

The teeth were placed into a glass beaker containing $500 \mathrm{ml}$ BHI broth (inoculated with bacteria) and incubated anaerobically at $37^{\circ} \mathrm{C}$, in a shake-incubator, for 7 days. Anaerobic incubation was accomplished by placing the glass beaker into a sealed anaerobic flask containing an Anerocult insert and the flask placed into an incubator. After 7 days the teeth were removed from the broth in an upright position retaining the suspension within the canals (Fig 14).

\section{Fig 14: Tooth removed from $\mathrm{BHI}$ broth and held upright (note BHI broth in beaker)}

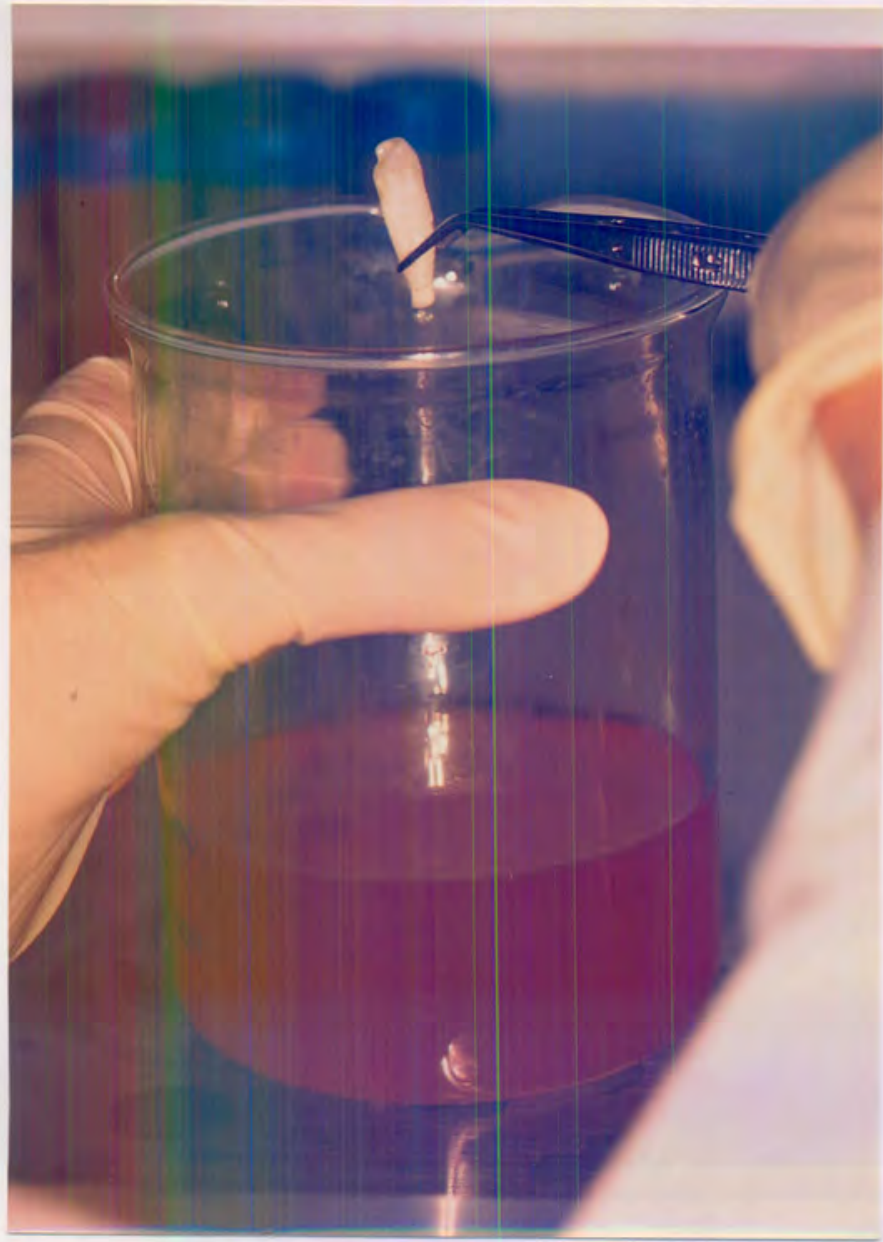


The suspension was aspirated from each canal and $25 \mu \mathrm{l}$ spread onto marked blood agar plates. The plates were incubated anaerobically at $37^{\circ} \mathrm{C}$ for seven days and the presence of organisms inside the canal of each tooth was confirmed by formation of colony forming units (exceeding 1000 per plate). Immediately following aspiration, each tooth was placed into a sterile, marked container that corresponded to the marked agar plate for that tooth.

\subsection{Irrigation of teeth}

The teeth were randomly divided into four groups $(n=15)$. All teeth were irrigated for 5 minutes, with the four different irrigation solutions (Table 1:) being delivered from an ultrasonic unit:

Table 1: Irrigation solutions and Groups

\begin{tabular}{l|l}
\hline $\begin{array}{l}\text { Group A } \\
(\mathrm{n}=15)\end{array}$ & $\begin{array}{l}\text { Distilled water (Control group) } \\
\text { (obtained from laboratory) }\end{array}$ \\
\hline $\begin{array}{l}\text { Group B } \\
(\mathrm{n}=15)\end{array}$ & $\begin{array}{l}\text { Sodium hypochlorite } \\
(\mathrm{Jik}-3.5 \% \text { concentration }) *\end{array}$ \\
\hline $\begin{array}{l}\text { Group C } \\
(\mathrm{n}=15)\end{array}$ & $\begin{array}{l}\text { ECA at } \mathrm{pH} 7.0 \\
(\text { Anolyte }) * *\end{array}$ \\
\hline $\begin{array}{l}\text { Group D } \\
(\mathrm{n}=15)\end{array}$ & $\begin{array}{l}\text { ECA at } \mathrm{pH} 9.0 \\
(\text { Anolyte }) * *\end{array}$ \\
\hline
\end{tabular}

* Jik is manufactured at this concentration and is within the range of $\mathrm{NaOCl}$ concentrations shown to be antimicrobial (Baumgartner and Quenin, 1992).

** The solutions for groups $C$ and D were produced by a STEDS unit ${ }^{16}$ set at a current of 5.0 Ampere.

\subsection{Second microbiological analysis}

Directly following irrigation, $25 \mu \mathrm{l}$ sterile BHI solution was injected into each canal and aspirated immediately. This procedure was repeated three times (rinsing the canal). The third and final $25 \mu \mathrm{l}$ aspirated BHI solution was inoculated into $5.0 \mathrm{ml} \mathrm{BHI}$ broth and measured by spectrophotometry.

\footnotetext{
${ }^{16}$ STEDS, Radical Waters, Vorna Valley, South Africa
} 
In the same manner, a further $25 \mu \mathrm{l} \mathrm{BHI}$ solution was aspirated and placed onto a blood agar plate and incubated anaerobically at $37^{\circ} \mathrm{C}$ for 7 days.

The access cavities were sealed using Fermit ${ }^{17}$, the teeth placed in distilled water and incubated anaerobically at $37^{\circ} \mathrm{C}$ for 7 days..Fermit was used to facilitate easy removal of the restoration. Canals were accessed after 7 days and spectrophotometric analysis and plate counts for colony forming units repeated.

\subsection{Statistical analysis}

Results of the standard plate counts and spectrophotometry were analyzed using analysis of variance (ANOVA) and Dunnett's one-tailed t-test to detect differences between the four groups and in particular to test for significant differences between the control group (Group A) and the other three groups (Groups B,C and D)

Multiple comparison analysis, using Scheffe, Duncan and Tukey tests, was done to pinpoint differences between groups.

A paired t-test was performed on spectrophotometric readings for each group, to determine whether significant growth of bacteria took place in the period directly following irrigation and the seventh day post-irrigation.

\subsection{Scanning electron microscopy}

Nine teeth were removed at various stages of the experiment (Table 2) and fixed in $2.5 \%$ gluteraldehyde and phosphate-buffered solution (0.1M) (Glauert, 1981). Teeth were sectioned longitudinally, using a low-speed (200 rpm), water cooled, diamond saw $^{18}$. All specimens were mounted on metal plates with conductive adhesive paste, critical point dried and sputter coated with an 80 micron thick layer of gold.

Scanning electron micrographs ${ }^{19}$ were taken at magnifications 100,1500 and 6000 of nine teeth (Table 2).

\footnotetext{
${ }^{17}$ Fermit, Vivadent Ets., FL-9494 Schaan, Lichtenstein

${ }^{18}$ Isomet, Buehler, Micro-Met Scientific, P.O.Box 84386 Greenside, South Africa

${ }^{19}$ JEOL 5800, Tokyo, Japan
} 
Table 2: Stages at which teeth were removed from study for SEM examination

Directly from inoculated BHI broth - no irrigation

Following irrigation with distilled water and no incubation

Following irrigation with distilled water and incubation for 7 days

Following irrigation with $\mathrm{NaOCl}$ and no incubation

Following irrigation with $\mathrm{NaOCl}$ and incubation for 7 days

Following irrigation with ECA pH 7.0 and no incubation.

Following irrigation with ECA pH 7.0 and incubation for 7 days

Following irrigation with ECA pH 9.0 and no incubation

Following irrigation with ECA pH 9.0 and incubation for 7 days

Note: Five (of the above nine) teeth were removed from the study before the first microbiological analysis and resulted in sample numbers $(n=13),(n=14),(n=14)$ and $(n=14)$ for the four groups (A, B, C \& D) respectively. The remaining four teeth examined by SEM were removed from the study, subsequent to the second microbiological analysis 


\section{CHAPTER 5}

\section{Results}

Results of the standard plate counts (colony forming units) and spectrophotometric analysis are given in Tables 3 and 4.

Table 3: Colony forming units and spectrophotometric values measured immediately after irrigation of root canals with four different solutions

\begin{tabular}{l|l|l|l|l|l}
\cline { 2 - 5 } & \multirow{2}{*}{$\begin{array}{l}\text { No. of } \\
\text { Teeth } \\
\text { (n) }\end{array}$} & \multicolumn{2}{l|}{ Colony forming units } & \multicolumn{2}{l}{$\begin{array}{l}\text { Spectrophotometric } \\
\text { values }\end{array}$} \\
\cline { 3 - 6 } & $\begin{array}{l}\text { Mean } \\
\left(4 \times 10^{1}\right) / \mathrm{ml}\end{array}$ & SD & Mean & SD \\
\hline $\begin{array}{l}\text { Group A } \\
\text { (Control) }\end{array}$ & 13 & $>1000^{*}$ & 0 & 0.6585 & 0.0959 \\
\hline $\begin{array}{l}\text { Group B } \\
\text { (NaOCl) }\end{array}$ & 14 & 0 & 0 & 0.0442 & 0.0134 \\
\hline $\begin{array}{l}\text { Group C } \\
\text { (ECA pH 7.0) }\end{array}$ & 14 & 693 & 253 & 0.5785 & 0.1914 \\
\hline $\begin{array}{l}\text { Group D } \\
\text { (ECA pH 9.0) }\end{array}$ & 14 & 525 & $418^{* *}$ & 0.6251 & 0.1377 \\
\hline * & & & & & \\
\hline
\end{tabular}

A standardized microbiological counting technique was applied (Harrigan and McCance 1970). Plates were divided into quadrants and a count exceeding 250 for a quadrant was recorded as exceeding 1000 for that plate.

** A high SD (standard deviation) value was recorded for this group, indicative of a high variation within the group $(\mathrm{CV}=79.6)$.

All of the canals in Group A showed more than 1000 colony forming units, indicating the inability of distilled water to destroy bacteria. The canals in Group B however, showed no colony formation and confirm the bactericidal action of $\mathrm{NaOCl}$. Groups $\mathrm{C}$ and D show less numbers of colony formation as well as reduced spectrophotometric values compared to the control group (Group A). This reduction however, does not approach the negative (zero) values as recorded for Group B and in fact are closer to those values obtained for the control group (Group A) 
Table 4: Colony forming units and spectrophotometric values measured seven days after irrigation of root canals with four different solutions

\begin{tabular}{|c|c|c|c|c|c|}
\hline & \multirow{2}{*}{$\begin{array}{l}\text { No. of } \\
\text { Teeth } \\
\text { (n) }\end{array}$} & \multicolumn{2}{|c|}{ Colony forming units } & \multicolumn{2}{|c|}{$\begin{array}{l}\text { Spectrophotometric } \\
\text { values }\end{array}$} \\
\hline & & $\begin{array}{l}\text { Mean } \\
\left(4 \times 10^{1}\right) / \mathrm{ml}\end{array}$ & SD & Mean & SD \\
\hline $\begin{array}{l}\text { Group A } \\
\text { (Control) }\end{array}$ & 13 & $>1000^{*}$ & 0 & 0.8458 & 0.1138 \\
\hline $\begin{array}{l}\text { Group B } \\
(\mathrm{NaOCl})\end{array}$ & 14 & $114 * *$ & 291 & 0.0654 & 0.0138 \\
\hline $\begin{array}{l}\text { Group C } \\
(\text { ECA pH 7.0) }\end{array}$ & 14 & 814 & 183 & 0.7524 & 0.1670 \\
\hline $\begin{array}{l}\text { Group D } \\
\text { (ECA pH 9.0) }\end{array}$ & 14 & 721 & 286 & 0.8082 & 0.2467 \\
\hline \multicolumn{6}{|c|}{$\begin{array}{l}\text { * A standardized microbiological counting technique was applied (Harrigan and McCance, } \\
\text { 1970). Plates were divided into four sections and a count exceeding } 250 \text { for a quadrant was } \\
\text { recorded as exceeding } 1000 \text { for that plate. }\end{array}$} \\
\hline \multicolumn{6}{|c|}{$\begin{array}{l}\text { ** Two of the fourteen plates had values of } 800 \text { (see Appendix II, pg.29, specimens } 20 \text { and } 28 \text { ), } \\
\text { resulting in a mean of } 114 \text { for the entire group. These colonies could be clearly identified as } \\
\text { contaminants. }\end{array}$} \\
\hline
\end{tabular}

All four groups show an increase in colony forming units and spectrophotometric values when compared to the results of the immediate post-irrigation analysis (Table 3). Values for Groups $C$ and $D$ once again approximate the values for Group $A$, and the values for Group B are almost negligible in comparison. If we discard the values of the contaminated plates in the colony forming unit count for Group B, a zero count is again recorded. 
Table 5: Increase in colony forming units and spectrophotometric values

for the period directly following irrigation to the seventh day post-irrigation (Table 4 minus Table 3)

\begin{tabular}{|c|c|c|c|}
\hline & \multirow{2}{*}{$\begin{array}{l}\text { No. of } \\
\text { Teeth } \\
\text { (n) }\end{array}$} & \multicolumn{2}{|l|}{ Mean *** } \\
\hline & & $\begin{array}{l}\text { Colony forming units } \\
\left(4 \times 10^{1}\right) / \mathrm{ml}\end{array}$ & $\begin{array}{l}\text { Spectrophotometric } \\
\text { values }\end{array}$ \\
\hline $\begin{array}{l}\text { Group A } \\
\text { (Control) }\end{array}$ & 13 & * & 0.1872 \\
\hline $\begin{array}{l}\text { Group B } \\
\text { (NaOCl) }\end{array}$ & 14 & $114^{* *}$ & 0.0211 \\
\hline $\begin{array}{l}\text { Group C } \\
\text { (ECA Ph 7.0) }\end{array}$ & 14 & 121 & 0.1738 \\
\hline $\begin{array}{l}\text { Group D } \\
\text { (ECA pH 9.0) }\end{array}$ & 14 & 196 & 0.1831 \\
\hline \multicolumn{4}{|c|}{ * This value could not be determined, due to the non-defined values exceeding 1000 . } \\
\hline $\begin{array}{l}\text { Two of th } \\
\text { These colc }\end{array}$ & $\begin{array}{l}\text { fourteen } \mathrm{p} \\
\text { iies could } \mathrm{b}\end{array}$ & $\begin{array}{l}\text { s had values of } 800 \text {, resulting } \\
\text { learly identified as contaminar }\end{array}$ & mean of 114 for the entire group. \\
\hline $\begin{array}{l}\text { Standard } \mathrm{d} \\
\text { no meanin }\end{array}$ & viation val & $\begin{array}{l}\text { are not given, as these were } \mathrm{r} \\
\text { on. }\end{array}$ & statistically representative and have \\
\hline
\end{tabular}

Once more, the values in Groups A, C and D are very close whilst the spectrophotometric value for Group B is at least $10^{1}$ less than that of the other groups and the number of colonies formed is again zero (disregarding contaminants) 
Table 6: Dunnett's test results on spectrophotometric values, comparing each of Groups B, C and D to Group A (Control)

\begin{tabular}{l|l|l}
\hline Comparison & Directly following irrigation & Seven days post-irrigation \\
\hline Group B to Control & $* * *$ & $* * *$ \\
\hline Group C to Control & - & - \\
\hline Group D to Control & - & - \\
\hline$* * * \quad$ denotes significant difference $(\mathrm{p} \leq 0.05)$ &
\end{tabular}

Spectrophotometric values for Group B differed significantly from Group A ( $\mathrm{p} \leq 0.05)$. The close approximation of values for Groups A, C and D was also demonstrated by this test ( $>0.05)$, (confirming what was seen in Tables 3, 4 and 5).

Table 7: Results of paired t-test on spectrophotometric values for bacterial growth over the seven day period after irrigation with four different solutions

\begin{tabular}{l|l|l}
\hline Group & Mean & p-value \\
\hline $\begin{array}{l}\text { Group A } \\
\text { (Control) }\end{array}$ & 0.1872 & $0.0001^{*}$ \\
\hline $\begin{array}{l}\text { Group B } \\
\text { (NaOCl) }\end{array}$ & $0.0211^{* *}$ & $0.0001^{*}$ \\
\hline $\begin{array}{l}\text { Group C } \\
\text { (ECA Ph 7.0) }\end{array}$ & 0.1738 & $0.0027^{*}$ \\
\hline $\begin{array}{l}\text { Group D } \\
\text { (ECA pH 9.0) }\end{array}$ & 0.1831 & $0.0015^{*}$ \\
\hline * Significant microbial growth was found in all four groups for the seven day period between \\
the measuring of microbial counts (p $\leq 0.05)$ \\
** Bacterial growth within the canals irrigated with $\mathrm{NaOCl}$ was at least one thousandth less than \\
that in any of the other three groups.
\end{tabular}




\section{SEM Examination}

Representative micrographs of the surfaces of the root canals are shown in Figures 15 to 22

Fig 15: No Irrigation (x 6000)

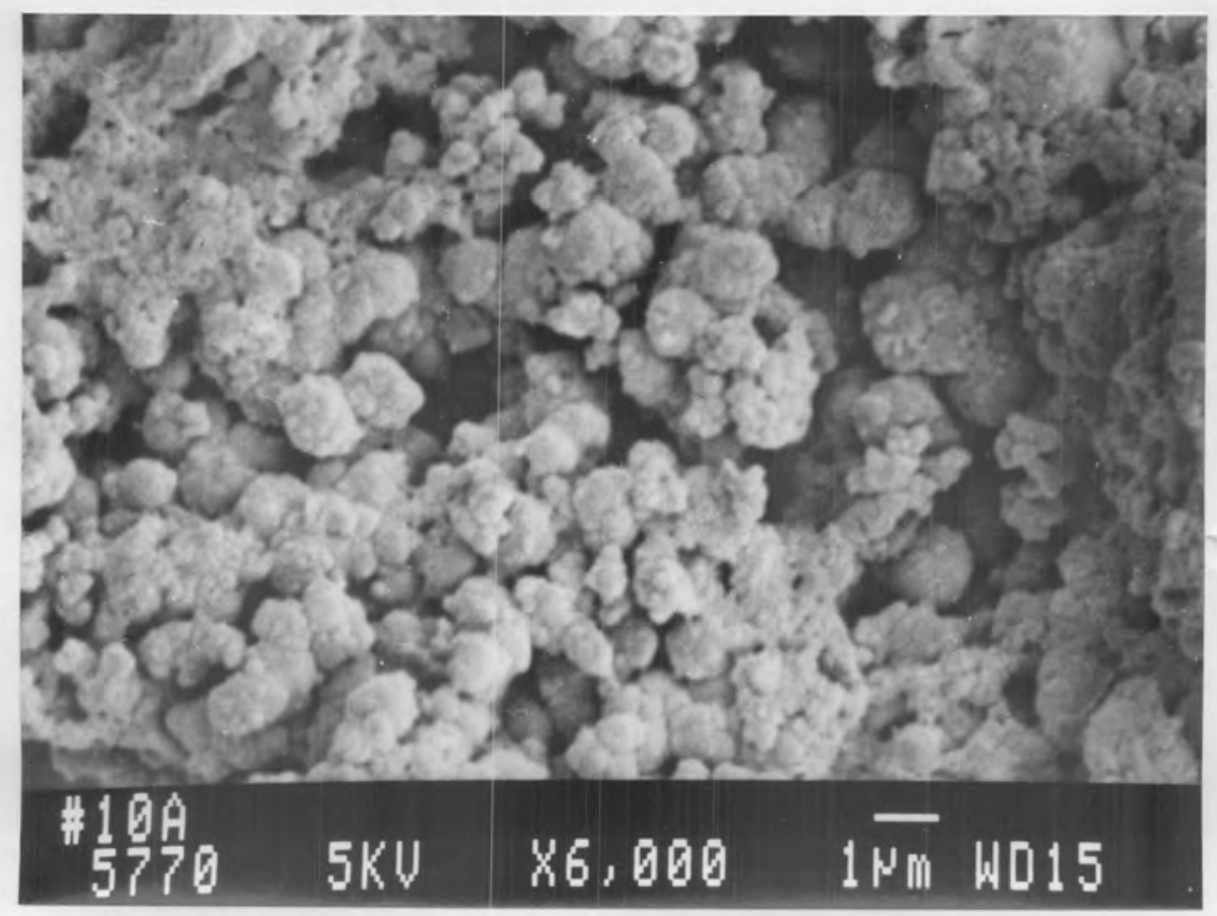

Fig 15: A layer of bacteria was seen on the entire surface of the canal in the control group (Group A), before irrigation was performed. (Original magnification x 6000; bar indicates 1 micron) 
Fig 16: Distilled water (x 6000)

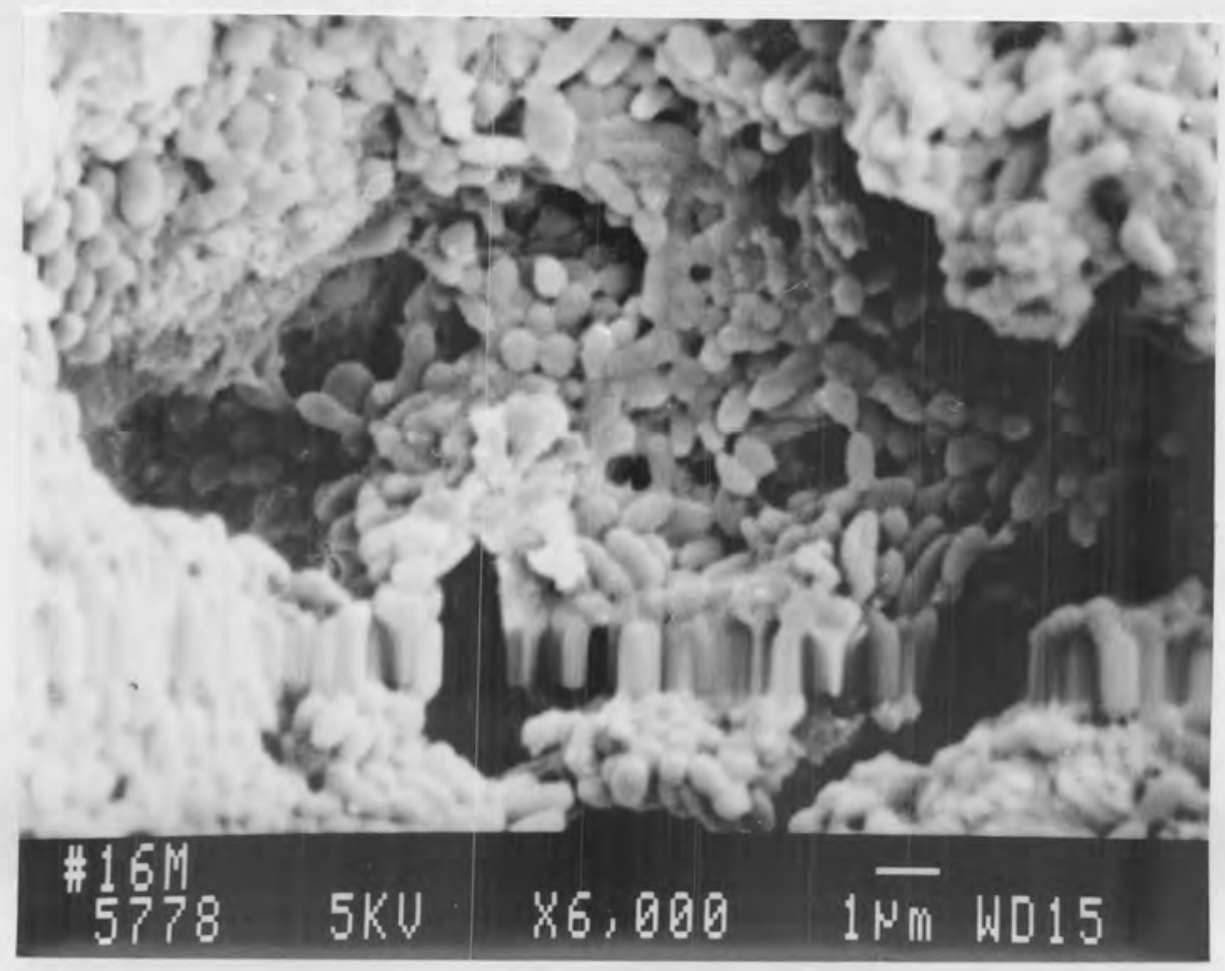

Fig 16: Surface of a root canal of a tooth in Group A following irrigation with distilled water. Abundant debris, presumably covering bacteria was seen. (Original magnification x 6000; bar indicates 1 micron)

Fig 17: $\mathrm{NaOCl}(\mathrm{x} 1500)$

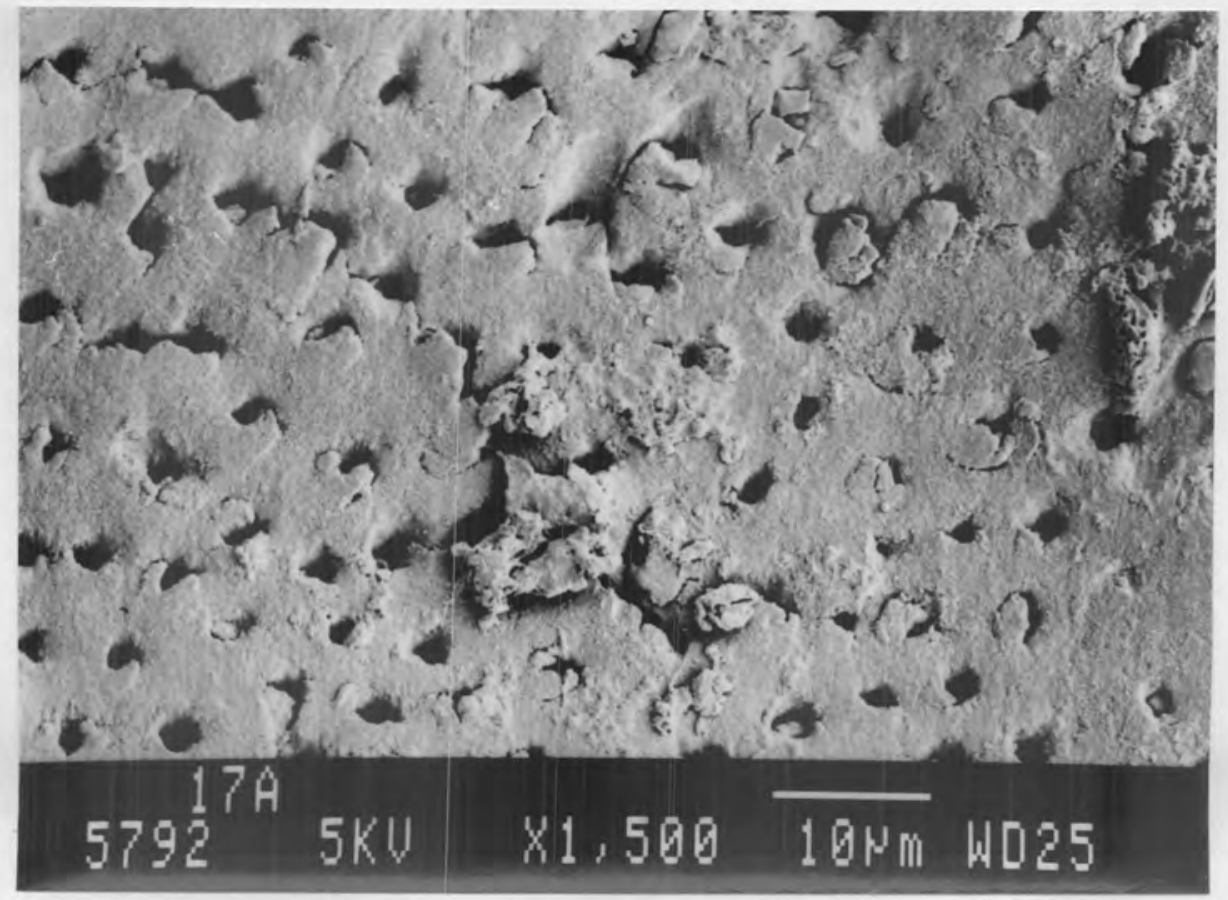

Fig 17: Surface of root canal of a tooth in Group B irrigated with $\mathrm{NaOCl}$. Note the presence of the smear layer partially occluding dentinal tubuli. (Original magnification x 1500; bar indicates 10 micron) 
Fig 18: $\mathrm{NaOCl}(\mathrm{x} 6000)$

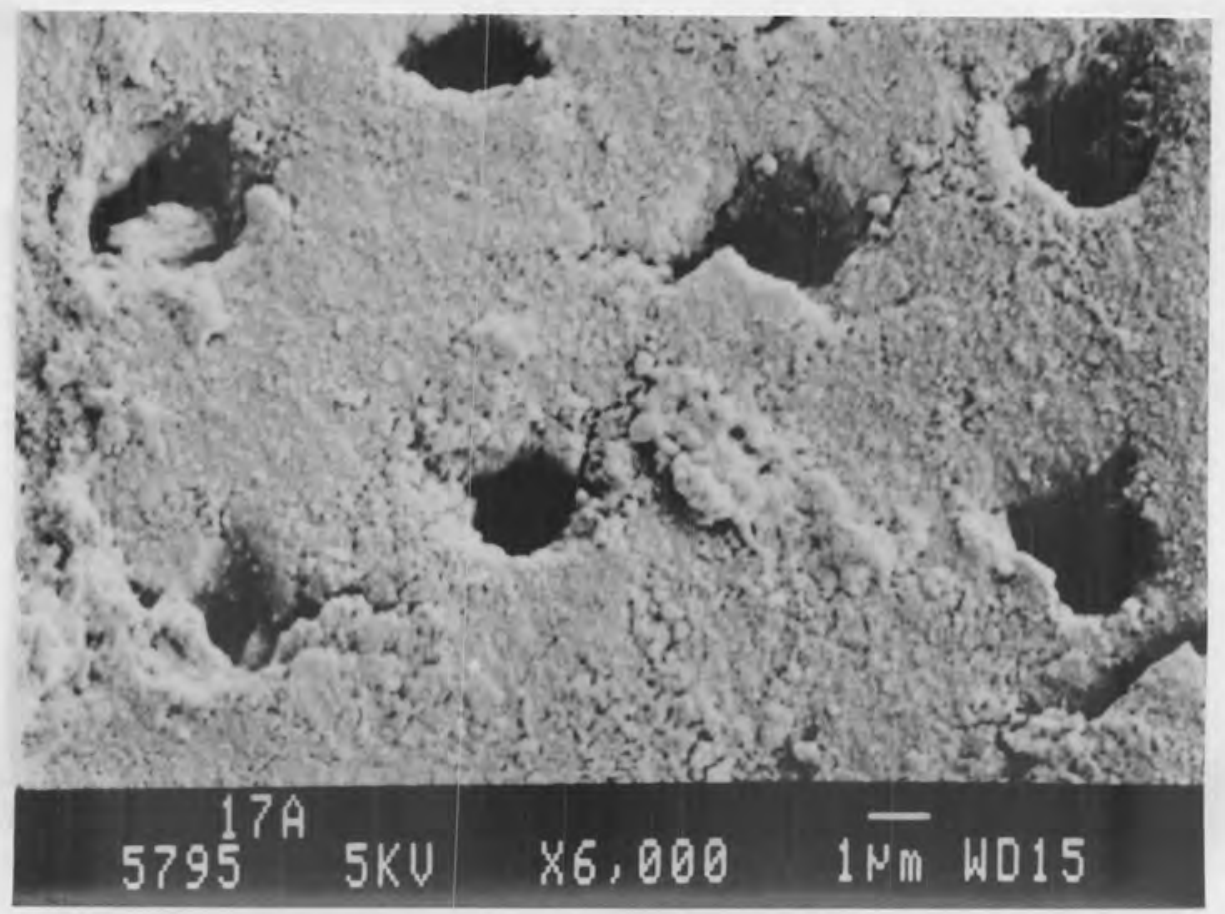

Fig 18: Higher magnification of area shown in Fig.17 (Original magnification x 6000; bar indicates 1 micron)

Fig 19: ECA pH 7.0 (x 1500)

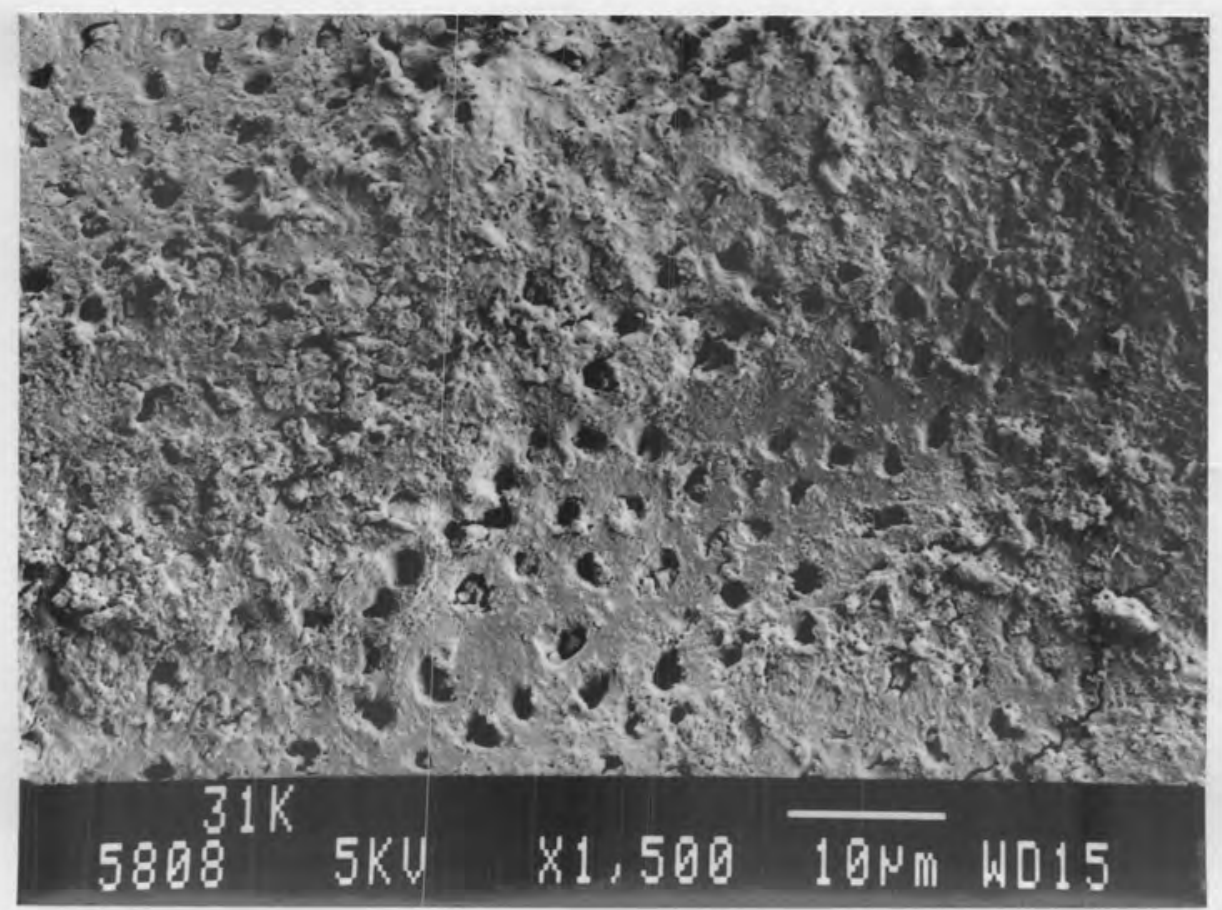

Fig 19: Surface of root canal of a tooth in Group $\mathrm{C}$ irrigated with ECA, pH 7.0. Lack of debris is evident. (Original magnification $\mathrm{x} 1500$; bar indicates 10 micron) 
Fig 20: ECA pH 7.0 (x 6000)

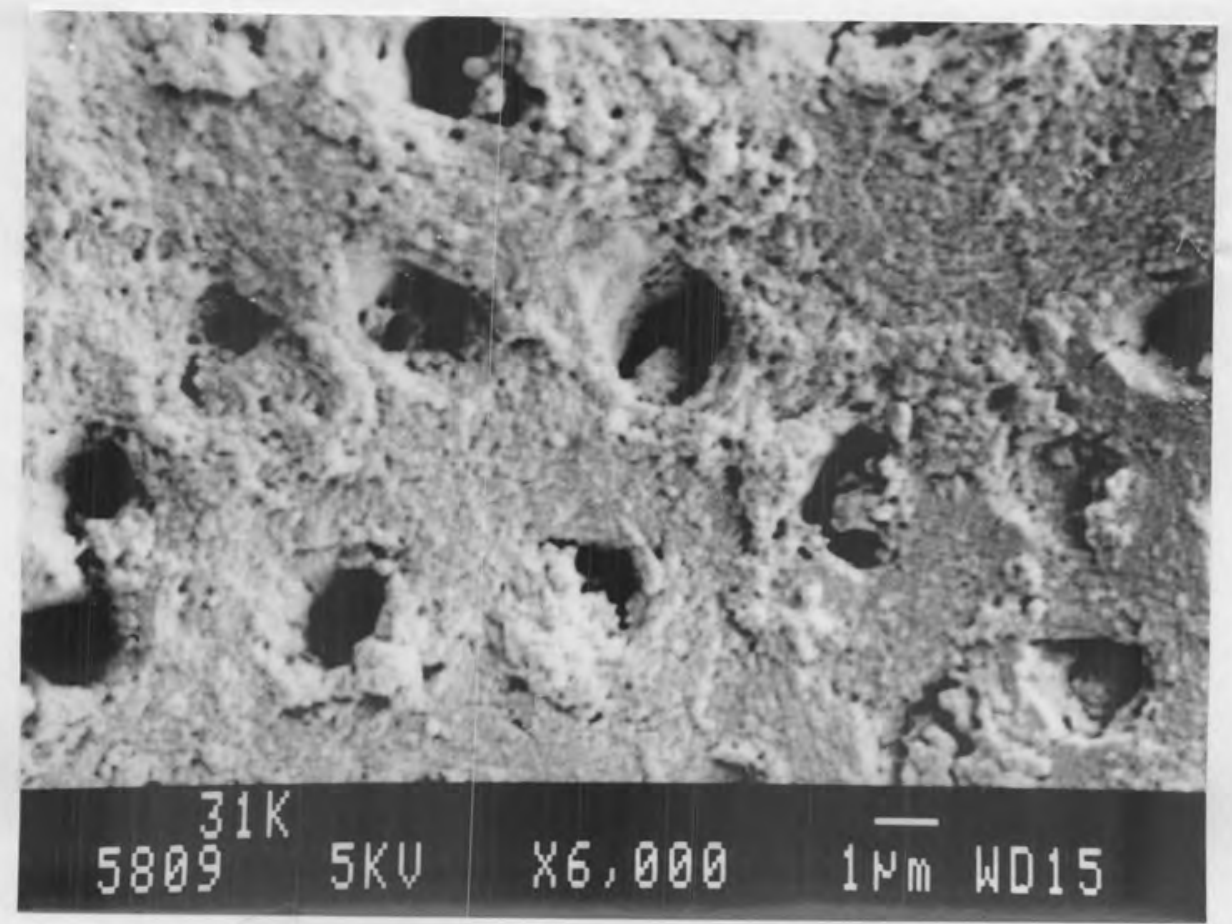

Fig 20: Higher magnification of area shown in Fig.19, showing thinner smear layer than that seen in Fig.18 ( NaOCl). (Original magnification x 6000; bar indicates 1 micron)

Fig 21: ECA pH 9.0 (x 1500)

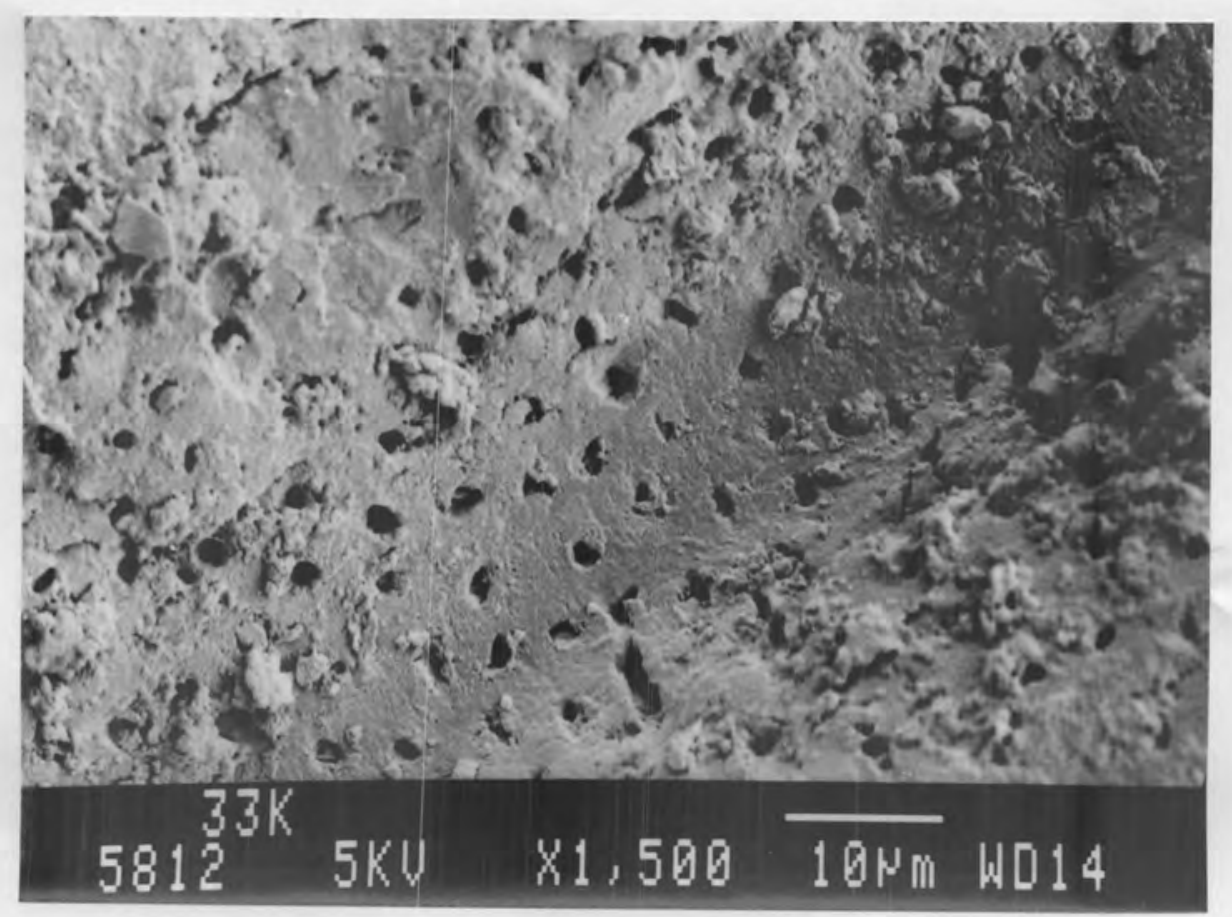

Fig 21: Surface of root canal of a tooth in Group D irrigated with ECA, pH 9.0 showing lack of debris or bacteria. (Original magnification x 1500; bar indicates 10 micron) 
Fig 22: ECA pH 9.0 (x 6000)

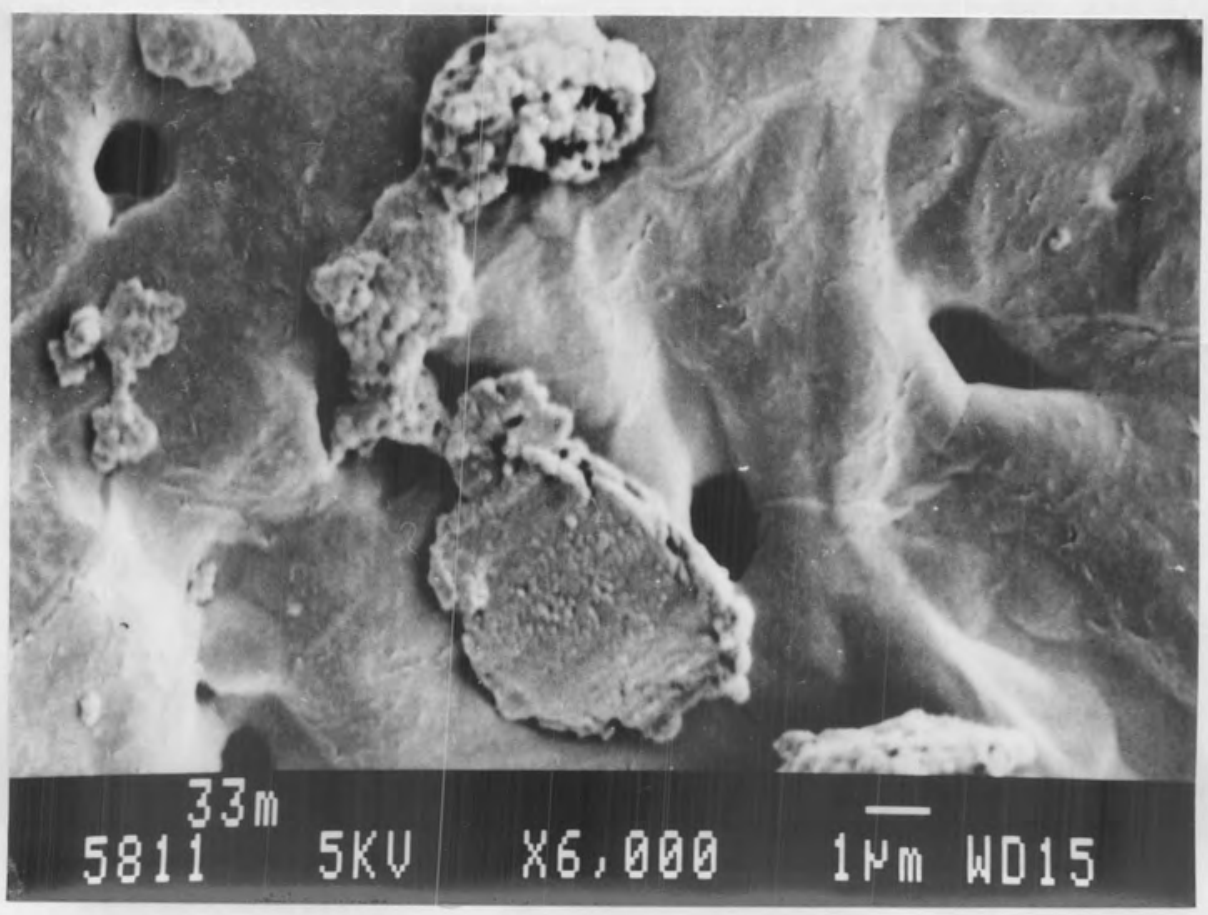

Fig 22: Higher magnification of root canal of a tooth in Group D irrigated with ECA, pH 9.0 (different tooth and root canal to that shown in Fig. 21 above), showing removal of smear layer. (Original magnification x 6000; bar indicates 1 micron) 


\section{CHAPTER 6}

\section{Discussion}

The selection of the four bacteria used in this study was based on the fact that they are all widely implicated pathogens in diseases of the pulp and periapical tissues. In addition, these bacteria have also been used, either as individual strains or in combination, in many in vitro studies of this nature (Safavi et al, 1990; Yesilsoy et al, 1995; Siqueira and de Uzeda, 1996; Siren et al, 1997; Siqueira et al, 1997; KwangShik et al, 1997; Barbosa et al, 1997; Siqueira and de Uzeda, M, 1997; Dougherty et al, 1998; Molander et al, 1998).

Taxonomic identification was not carried out for growth on the culture medium and thus any and all remaining bacteria were included in the colony forming unit count. Because the study was conducted on a limited number of pure cultured (ATCC, USA) anaerobic bacteria and under sterile conditions, there was no intention or need to do taxonomic identification.

Contamination was apparent in only two of the total number of 240 plates cultured and this was easily identified (green, mucous patches) and did not affect our findings. Of interest, is the fact that this contamination was found in the group irrigated with $\mathrm{NaOCl}$.

All of the cultures for the control group had bacterial counts exceeding 1000 colony forming units, representative of active bacterial growth. The fact that these bacteria successfully withstood vigorous irrigation (ultrasonics) with distilled water and to a lesser extent, irrigation with ECA, proves that the four selected species of bacteria are a useful model for a study of this kind.

The fact that colony forming units consistently exceeded 1000 (undefined) in the control group (Group A), was reason to consider a larger dilution factor (i.e. $>4 \times 10^{1}$ ). Should defined counts have been possible, this would have made statistical evaluation even more accurate. 
However, the probability of recording 'false-negative' (decreased sensitivity for the test) counts for Groups C and D (see Appendix I-specimens 48, 54, 55, 56 and 59) would have been more detrimental to the results and the dilution factor thus used was $4 \times 10^{1}(0.25 \mu \mathrm{l})$

Under the conditions of this study, ECA failed to destroy all of the bacteria within the root canals of the teeth studied. On the other hand $\mathrm{NaOCl}$ reduced the bacterial counts to less than 1 colony forming unit / $25 \mu$ in all of the specimens. This was the case both directly following irrigation and very importantly, also seven days postirrigation. Table 7 shows that although there was an increase in the number of bacteria present in the root canals over the seven day incubation period, Group B $(\mathrm{NaOCl})$ had by far the least $(\mathrm{Mean}=0.0211)$. This confirms the total antimicrobial action of $\mathrm{NaOCl}$.

The control group consistently (15 from 15 counts at each analysis) produced bacterial counts greater than 1000 colony forming units/ $25 \mu \mathrm{l}$, confirming the accuracy and usefulness of this model for similar studies. The results of the spectrophotometric analysis correlated well with those for the colony forming units (as seen in Tables 3, 4 and 5), further confirming the relevance of this model. Although subjective, visual examination by SEM supported these findings by showing many bacteria in the control group and no bacteria in the group irrigated with $\mathrm{NaOCl}$. Varying numbers of bacteria were seen for the groups irrigated with ECA (Fig.15-22).

The large variation (SD) recorded for colony forming units for Group D (Table 3) could not be accounted for. Thorough investigation as to the possible reason for this occurrence revealed no explanation. The very low (groups A and B) and low (Group C) variation, of all three other groups, seem to indicate that the experimental model and techniques used were accurate. This, together with the fact that values for spectrophotometry indicate an acceptable level of variation (2SD) in all four groups and furthermore, the fact that this high variation was not seen in the measurements taken seven days post-irrigation, give further reason to accept this model as accurate. 
Although fewer bacteria were measured and seen (SEM) in the groups irrigated with ECA (compared to Group A, control) both directly following irrigation and seven days post-irrigation, ECA was not as effective in destroying bacteria as was $\mathrm{NaOCl}$. Various reasons for this apparent failure may be given. Firstly, there may be an inherent problem with the technological production of ECA, however, in the light of the successful pilot studies conducted prior to commencement of this study, this is doubtful. Secondly, the results of earlier work on ECA (Marais, 1998) suggest that eradication of bacteria within the root canal system may be achieved with the use of ECA, another inconsistency with the apparent failure of ECA in this study.

A more likely explanation may be one of the following:

1. At the time of preparation of the ECA solutions used in this study, a technical failure of the unit may have resulted in an altered ECA solution. This would indicate the technique sensitivity in the production of ECA for use as an endodontic solution and indicates the need for quality control of the technology.

2. The specific ECA parameters ( $\mathrm{pH}$, current, temperature, exposure time of canal to irrigant, flow rate) used in this study may need to be varied and will be studied in future research. As can be expected in any system with so many variables, and given the metastable state of the solution, one can expect to have initial difficulties in identifying the exact parameters required for a successful antimicrobial solution for use in the root canal system.

3. In the study by Marais (1998), the irrigation procedure with the anolyte was preceded by a similar rinse with catholyte. In the present study, only anolyte was used. The use of anolyte and catholyte in combination, should be investigated further. 


\section{CHAPTER 7}

\section{Conclusion}

1. In accordance with many other studies, $\mathrm{NaOCl}(3,5 \%)$ was shown to be completely bactericidal within the root canal system.

2. The use of ECA caused a reduction in the number of anaerobic bacteria within the root canal system, but this was not statistically significant $(\mathrm{p}>0.05)$.

3. The model used for this study is proposed for future research into antimicrobial effectiveness against anaerobic bacteria in the root canal system.

"It is not enough that you should understand about applied science in order that your work may increase man's blessings. Concern for Man himself and his fate must always form the chief interest of all technical endeavors.... In order that the creations of our mind shall be a blessing and not a curse to mankind-never forget this in the midst of your diagrams and equations." Albert Einstein 


\section{REFERENCES}

American Association of Endodontics recertification document, (1989)

Barbosa CAM, Goncalves RB, Siqueira JF, de Uzeda M (1997) Evaluation of the antibacterial activities of calcium hydroxide, chlorhexidine, and camphorated paramonochlorophenol as intracanal medicament. A clinical and laboratory study. Journal Of Endodontics 23, 297-299.

Baumgartner JC, Cuenin PR (1992) Efficacy of several concentrations of sodium hypochlorite for root canal irrigation. Journal Of Endodontics 18, 605-612.

Behrend GD, Cutler CW, Gutmann JL (1996) An in vitro study of smear layer removal and microbial leakage along root-canal fillings. International Endodontic Journal 29, 99-107.

Brown DC, Moore BK, Brown CE Jr., Newton CW (1995) An in vitro study of apical extrusion of sodium hypochlorite during endodontic canal preparation. Journal of Endodontics 21, 587-591.

Caliskan MK, Turkun M, Alper S (1994) Allergy to sodium hypochlorite during root canal therapy: a case report. International Endodontic Journal 27, 163-167.

Cameron JA (1995) Factors affecting the clinical efficiency of ultrasonic endodontics: a scanning electron microscopy study. International Endodontic Journal 28, 47-53.

Cheung GS, Stock CJR (1993) In vitro cleaning ability of root canal irrigants with and without endosonics. International Endodontic Journal 26, 334-343.

Cymbler DM, Ardakani P (1994) Sodium hypochlorite injection into periapical tissues. Dental Update 21, 345-346. 
Dougherty WJ, Bae KS, Watkins MS, Baumgartner JC (1998) Black-pigmented bacteria in coronal and apical segments of infected root canals. Journal of Endodontics 24, 356-358.

Fegan SE, Steiman HR (1995) Comparative evaluation of the antibacterial effects of intracanal Nd-YAG laser irradiation: an in vitro study. Journal of Endodontics 21, 415-417.

Georgopoulou M, Kontakiotis E, Nakou M (1994) Evaluation of the antimicrobial effectiveness of citric acid and sodium hypochlorite on the anaerobic flora of the infected root canal. International Endodontic Journal 27, 139-143.

Glauert AM (1981) Fixation, Dehydration and Embedding of Biological Specimens. In: Practical Methods In Electron Microscopy: $4^{\text {th }}$ Edition, North Holland Publishing Company, Amsterdam.

Gulabivala K, Stock CJR (1995) Preparation of the root canal. In: Color Atlas and Text of Endodontics. $2^{\text {nd }}$ Edition, Mosby-Wolfe, 97-144.

Harrigan WF, McCance ME (1970) Laboratory Methods in Microbiology. Part1:3435. London Academic Press.

Hata G-I, Uemura M, Weine F, Toda T (1996) Removal of smear layer in the root canal using oxidative potential water. Journal of Endodontics 22, 643-645.

Jeansonne MJ, White RR (1994) A comparison of $2 \%$ chlorhexidine gluconate and $5,25 \%$ sodium hypochlorite as antimicrobial endodontic irrigants. Journal of Endodontics 20, 276-278.

Jimenez-Rubio A, Segura JJ, Llamas R, Jimenez-Planas A, Guerrero JM, Calvo JR (1997) In vitro study of the effect of sodium hypochlorite and gluteraldehyde on substrate adherence capacity of macrophages. Journal of Endodontics 23,562-564 
Kwang-Shik Bae, Baugartner JC, Shearer TR, David LL (1997) Occurrence of Prevotella nigrescens and Prevotella intermedia in infections of endodontic origin. Journal of Endodontics 23, 620-623.

Marais JT (1998) Cleaning efficacy of a new root canal irrigation material Journal of Dental Research 77, Abstract 300, 669.

Molander A, Reit C, Dahlen G, Kvist, T (1998) Microbiological status of root- filled teeth with apical periodontitis. International Endodontic Journal 31, 1-7.

Safavi K, Spangberg L, Langeland K (1990) Root canal dentinal tubule disinfection. Journal of Endodontics 16, 207-210.

Siqueira JF, Machado AG, Silveira RM, Lopes HP, de Uzeda, M (1997) Evaluation of the effectiveness of sodium hypochlorite used with three irrigation methods in the elimination of Enterococcus faecalis from the root canal, in vitro. International Endodontic Journal 30, 279-282.

Siqueira JF, de Uzeda, M (1996) Disinfection by calcium hydroxide pastes of dentinal tubules infected with two obligate and one facultative anaerobic bacteria. Journal of Endodontics 22, 674-676.

Siqueira, JF, de Uzeda M (1997) Intracanal medicaments: Evaluation of the antibacterial effects of chlorhexidine, metronidazole, and calcium hydroxide associated with three vehicles. Journal of Endodontics 23, 167-169.

Siren EK, Haapasalo MPP, Ranta K, Salmi P, Kerusuo E.N.J (1997) Microbiological findings and clinical treatment procedures in endodontic cases selected for microbiological investigation. International Endodontic Journal 30, 91-95.

Turkun M, Cengiz, T (1997) The effects of sodium hypochlorite and calcium hydroxide on tissue dissolution and root canal cleanliness. International Endodontic Journal 30, 335-342. 
Walton RE, Rivera, EM (1996) Cleaning and shaping. In: Principles and Practice of Endodontics. $2^{\text {nd }}$ Edition WB Saunders, Philadelphia 201-233.

Yesilsoy C, Whitaker E, Cleveland D, Phillips E, Trope M (1995) Anti-microbial and toxic effects of established and potential root canal irrigants. Journal of Endodontics 21, 513-515. 


\section{ADDENDA}

\section{Appendix A}

Colony forming units and spectrophotometric analysis measured directly after Irrigation

\begin{tabular}{|c|c|c|c|c|c|}
\hline $\begin{array}{l}\text { Specimen } \\
\text { Number }\end{array}$ & $\begin{array}{c}\text { Colony } \\
\text { forming } \\
\text { units } \\
\left(4 \times 10^{1}\right) / \mathrm{ml}\end{array}$ & $\begin{array}{c}\text { Spectrometric } \\
\text { analysis }\end{array}$ & $\begin{array}{l}\text { Specimen } \\
\text { Number }\end{array}$ & $\begin{array}{c}\text { Colony } \\
\text { forming } \\
\text { units } \\
\left(4 \times 10^{1}\right) / \mathrm{ml}\end{array}$ & $\begin{array}{c}\text { Spectrometric } \\
\text { analysis }\end{array}$ \\
\hline 1 & $>1000$ & 0,5504 & 31 & $\mathrm{XXXXXX}$ & $\mathrm{XXXXXXX}$ \\
\hline 2 & $>1000$ & 0,5851 & 32 & $>1000$ & 0,5690 \\
\hline 3 & $>1000$ & 0,6386 & 33 & $>1000$ & 0,6045 \\
\hline 4 & $>1000$ & 0,6167 & 34 & $>800$ & 0,5185 \\
\hline 5 & $>1000$ & 0,6193 & 35 & $>500$ & 0,8329 \\
\hline 6 & XXXXXX & XXXXXXX & 36 & $>1000$ & 0,5773 \\
\hline 7 & XXXXXX & $\mathrm{XXXXXXX}$ & 37 & $>500$ & 0,5639 \\
\hline 8 & $>1000$ & 0,7340 & 38 & $>500$ & 0,6995 \\
\hline 9 & $>1000$ & 0,6080 & 39 & $>500$ & 0,4952 \\
\hline 10 & $>1000$ & 0,7985 & 40 & $>1000$ & 0,5559 \\
\hline 11 & $>1000$ & 0,6096 & 41 & $>500$ & 0,5074 \\
\hline 12 & $>1000$ & 0,7083 & 42 & $>500$ & 0,5549 \\
\hline 13 & $>1000$ & 0,8843 & 43 & $>500$ & 0,7138 \\
\hline 14 & $>1000$ & 0,5960 & 44 & $>400$ & 0,0473 \\
\hline 15 & $>1000$ & 0,6129 & 45 & $>1000$ & 0,8599 \\
\hline 16 & XXXXXX & XXXXXXX & 46 & XXXXXX & XXXXXXX \\
\hline 17 & 0 & 0,0429 & 47 & $>1000$ & 0,7656 \\
\hline 18 & 0 & 0,0371 & 48 & 46 & 0,7507 \\
\hline 19 & 0 & 0,0461 & 49 & $>300$ & 0,5529 \\
\hline 20 & 0 & 0,0679 & 50 & $>1000$ & 0,4822 \\
\hline 21 & 0 & 0,0426 & 51 & $>800$ & 0,5688 \\
\hline 22 & 0 & 0,0458 & 52 & $>800$ & 0,7222 \\
\hline 23 & 0 & 0,0396 & 53 & $>1000$ & 0,5539 \\
\hline 24 & 0 & 0,0305 & 54 & 30 & 0,5621 \\
\hline 25 & 0 & 0,0110 & 55 & 92 & 0,4924 \\
\hline 26 & 0 & 0,0561 & 56 & 77 & 0,5840 \\
\hline 27 & 0 & 0,0471 & 57 & $>800$ & 0,9350 \\
\hline 28 & 0 & 0,0554 & 58 & $>300$ & 0,5249 \\
\hline 29 & 0 & 0,0413 & 59 & 103 & 0,4898 \\
\hline 30 & 0 & 0,0565 & 60 & $>1000$ & 0,7675 \\
\hline
\end{tabular}

'XXX' denotes teeth for SEM evaluation 


\section{Appendix B}

Colony forming units and spectrophotometric analysis measured seven days after irrigation

\begin{tabular}{|c|c|c|c|c|c|}
\hline $\begin{array}{l}\text { Specimen } \\
\text { Number }\end{array}$ & $\begin{array}{c}\text { Colony } \\
\text { forming } \\
\text { units } \\
\left(4 \times 10^{1}\right) / \mathrm{ml}\end{array}$ & $\begin{array}{l}\text { Spectrometric } \\
\text { analysis }\end{array}$ & $\begin{array}{l}\text { Specimen } \\
\text { Number }\end{array}$ & $\begin{array}{c}\text { Colony } \\
\text { forming } \\
\text { units } \\
\left(4 \times 10^{1}\right) / \mathrm{ml}\end{array}$ & $\begin{array}{c}\text { Spectrometric } \\
\text { analysis }\end{array}$ \\
\hline 1 & $>1000$ & 0,6980 & 31 & XXXXXX & XXXXXXX \\
\hline 2 & $>1000$ & 0,6901 & 32 & $>1000$ & 0,6687 \\
\hline 3 & $>1000$ & 0,8339 & 33 & $>1000$ & 0,7445 \\
\hline 4 & $>1000$ & 0,7865 & 34 & $>1000$ & 0,6329 \\
\hline 5 & $>1000$ & 0,8976 & 35 & $>800$ & 0,8936 \\
\hline 6 & $\mathrm{XXXXXX}$ & XXXXXXX & 36 & $>1000$ & 0,6715 \\
\hline 7 & $\mathrm{XXXXXX}$ & $\mathrm{XXXXXXX}$ & 37 & $>600$ & 0,5998 \\
\hline 8 & $>1000$ & 0,8310 & 38 & $>600$ & 0,7002 \\
\hline 9 & $>1000$ & 0,9802 & 39 & $>800$ & 0,6653 \\
\hline 10 & $>1000$ & 1,0140 & 40 & $>1000$ & 0,7994 \\
\hline 11 & $>1000$ & 0,7834 & 41 & $>600$ & 0,7574 \\
\hline 12 & $>1000$ & 0,8511 & 42 & $>600$ & 0,6182 \\
\hline 13 & $>1000$ & 0,9971 & 43 & $>800$ & 0,8077 \\
\hline 14 & $>1000$ & 0,9354 & 44 & $>600$ & 0,7155 \\
\hline 15 & $>1000$ & 0,6981 & 45 & $>1000$ & 1,2590 \\
\hline 16 & XXXXXX & XXXXXXX & 46 & XXXXXX & XXXXXXX \\
\hline 17 & 0 & 0,0852 & 47 & $>1000$ & 0,8551 \\
\hline 18 & 0 & 0,0512 & 48 & $>600$ & 0,8147 \\
\hline 19 & 0 & 0,0653 & 49 & $>800$ & 0,6345 \\
\hline 20 & $>800$ & 0,0799 & 50 & $>1000$ & 0,8686 \\
\hline 21 & 0 & 0,0532 & 51 & $>800$ & 0,7347 \\
\hline 22 & 0 & 0,0776 & 52 & $>800$ & 1,3772 \\
\hline 23 & 0 & 0,0597 & 53 & $>1000$ & 0,7598 \\
\hline 24 & 0 & 0,0411 & 54 & $>400$ & 0,6735 \\
\hline 25 & 0 & 0,0451 & 55 & $>300$ & 0,5617 \\
\hline 26 & 0 & 0,0774 & 56 & $>300$ & 0,6250 \\
\hline 27 & 0 & 0,0617 & 57 & $>1000$ & 1,2942 \\
\hline 28 & $>800$ & 0,0762 & 58 & $>800$ & 0,6440 \\
\hline 29 & 0 & 0,0683 & 59 & $>300$ & 0,5981 \\
\hline 30 & 0 & 0,0741 & 60 & $>1000$ & 0,8747 \\
\hline
\end{tabular}

'XXX' denotes teeth for SEM evaluation 


\section{Appendix C}

The anolyte produced at the anode contains $\mathrm{Cl}_{2}, \mathrm{HClO}, \mathrm{ClO}^{-}, \mathrm{ClO}, \mathrm{Cl}, \mathrm{HO}_{2}, \mathrm{HO}_{2}$, $\mathrm{O}_{2}, \mathrm{HO}, \mathrm{O}_{3}, \mathrm{O}_{2},{ }^{3} \mathrm{O}_{2},{ }^{1} \mathrm{O}_{2}, \mathrm{O}, \mathrm{H}_{3} \mathrm{O}^{+}, \mathrm{Cl}, \mathrm{H}^{-}, \mathrm{H}_{2} \mathrm{O}_{2}, \mathrm{Cl}_{2} \mathrm{O}, \mathrm{ClO}_{2}^{-}, \mathrm{HCl}, \mathrm{Cl}_{2} \mathrm{O}_{7}, \mathrm{~S}_{2} \mathrm{O}_{8}{ }^{8-}$, $\mathrm{C}_{2} \mathrm{O}_{6}{ }^{2-}, \mathrm{HclO}, \mathrm{H}_{2} \mathrm{SO}_{4}$, and $\mathrm{HSO}_{3} \mathrm{Cl}$.

The catholyte produced at the cathode contains $\mathrm{HO}^{-}, \mathrm{H}_{3} \mathrm{O}_{2}^{-}, \mathrm{O}_{2}^{-}, \mathrm{HO}_{2}^{-}, \mathrm{H}_{2} \mathrm{O}_{2}, \mathrm{H}_{2}, \mathrm{HO}$, $\mathrm{H}_{2}^{-}, \mathrm{NaOH}, \mathrm{KOH}, \mathrm{Ca}(\mathrm{OH})_{2}$ and $\mathrm{Mg}(\mathrm{OH})_{2}$

$\begin{array}{lllllllll}\text { (Radical Waters (Pty)Ltd., } & \text { P.O } & \text { Box } & 10844 & \text { Vorna } & \text { Valley, } & 1686, & \text { South Africa) }\end{array}$

